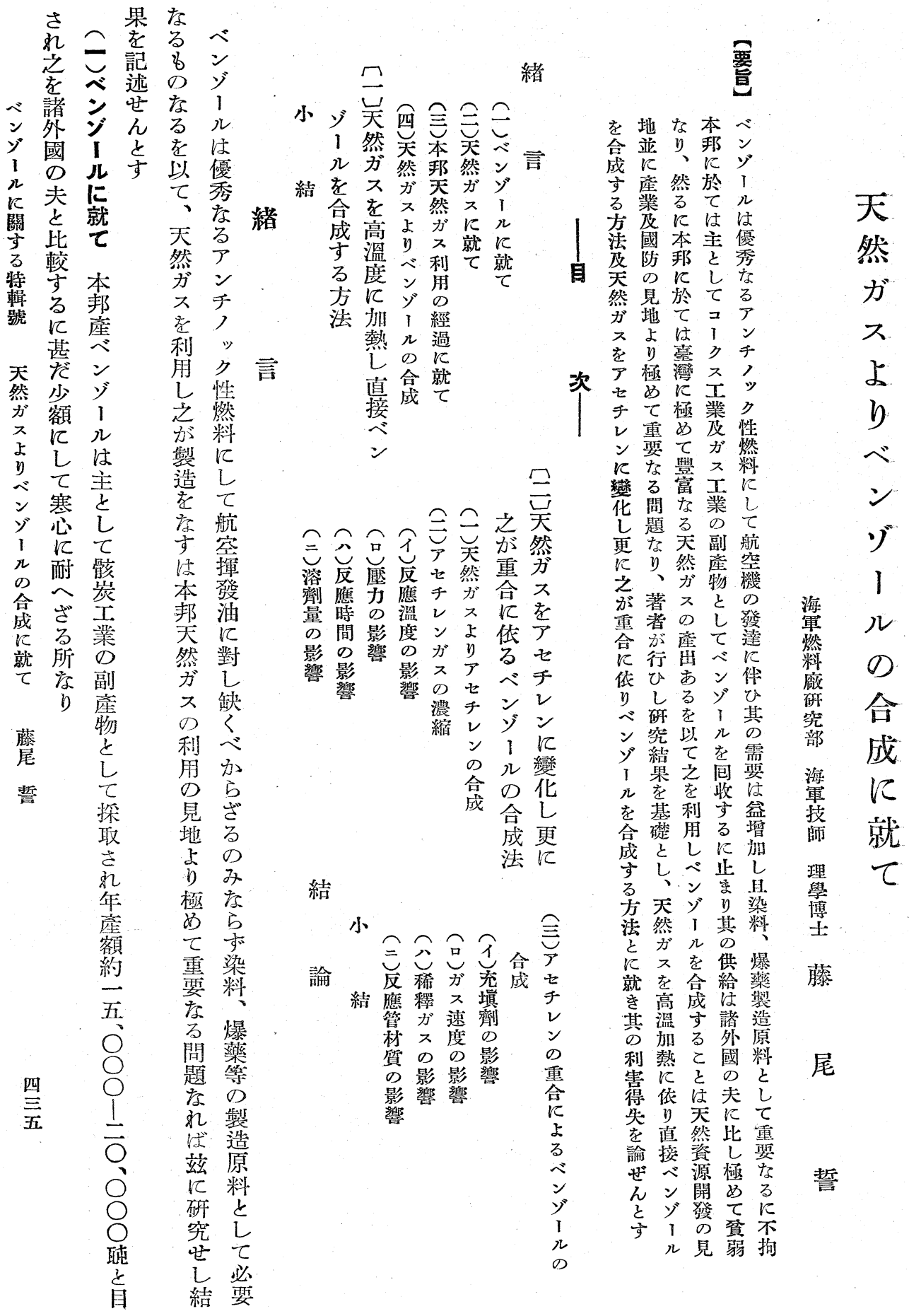




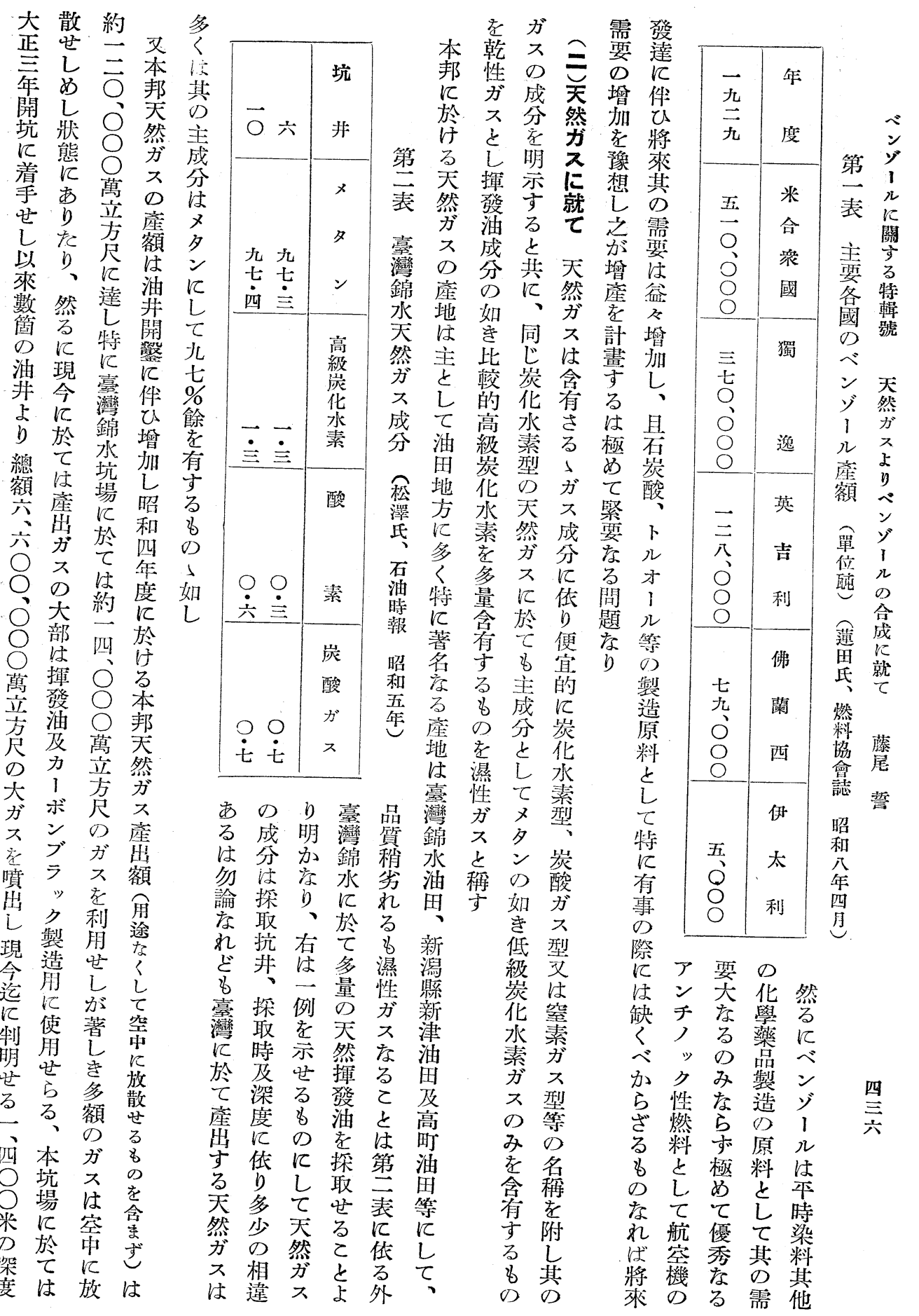


縮导

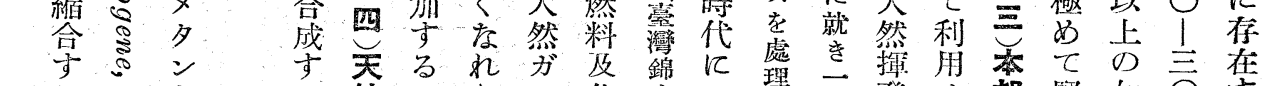

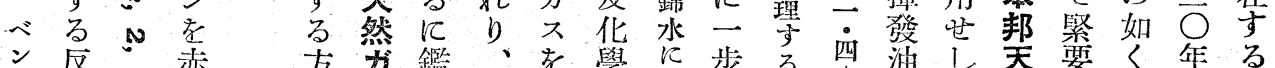

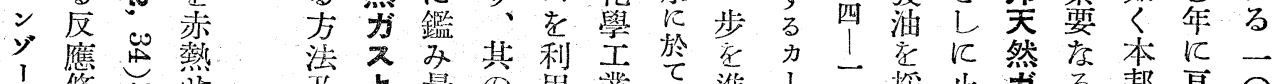

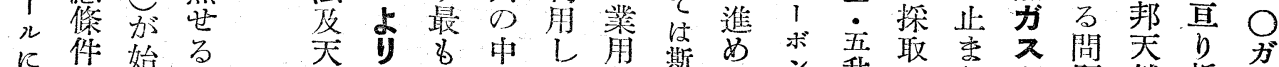

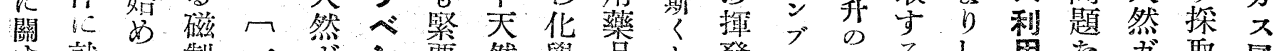

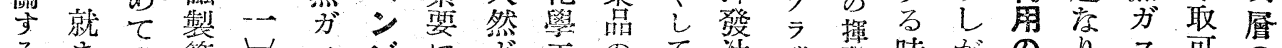

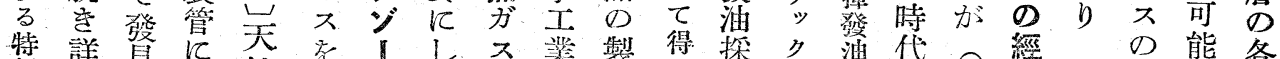

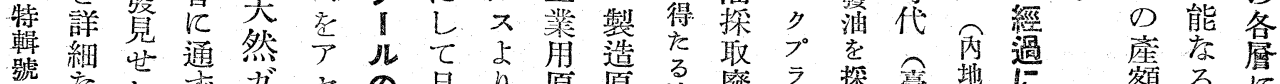

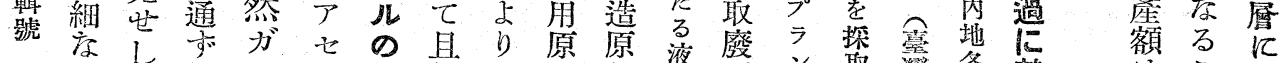

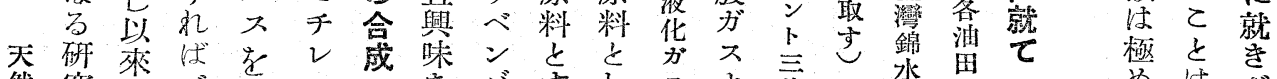
然誻

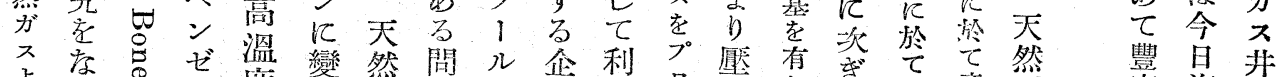

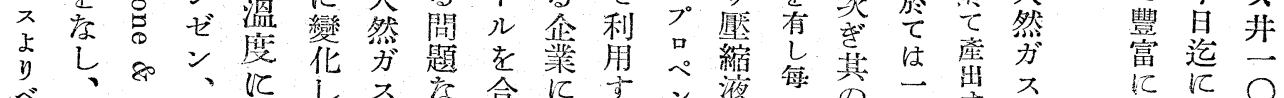

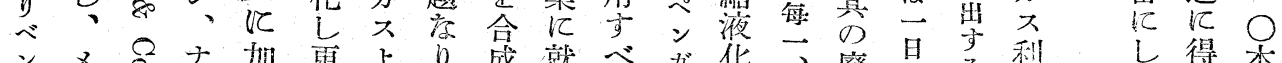

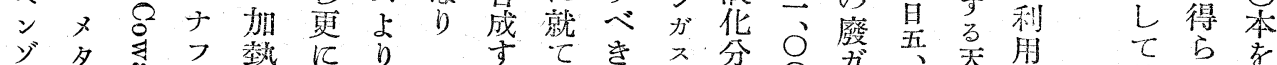

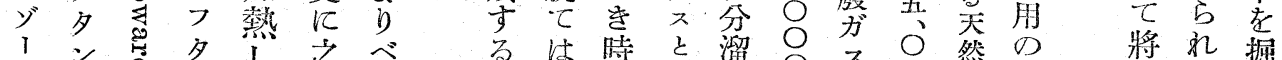

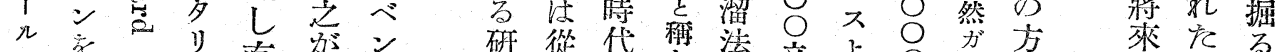

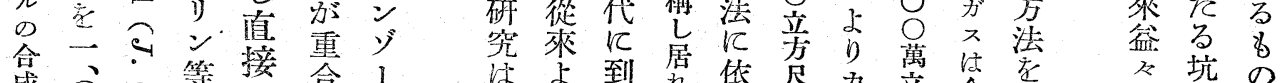

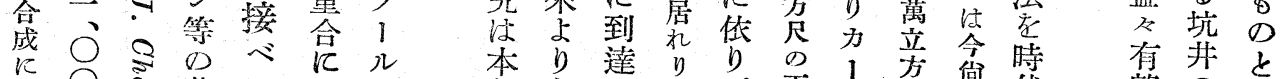

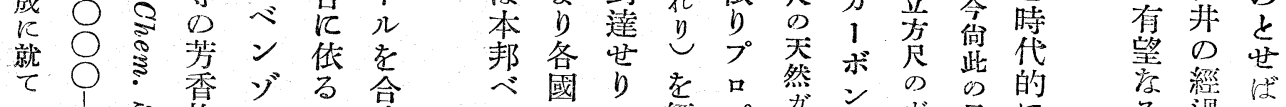

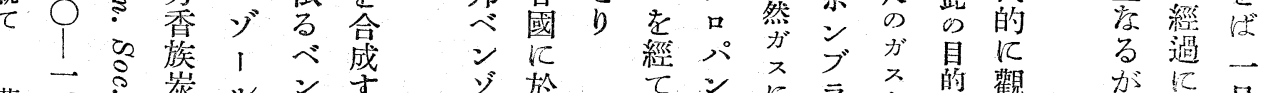
藤三。

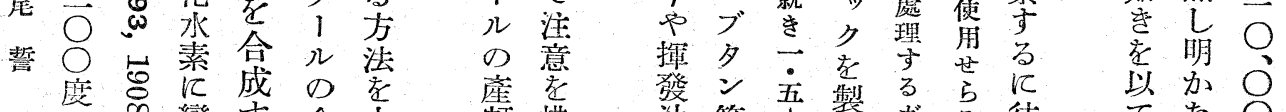

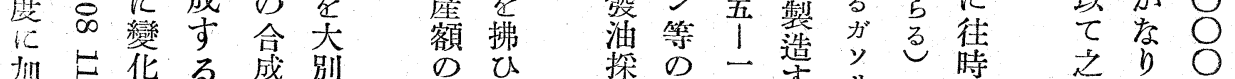

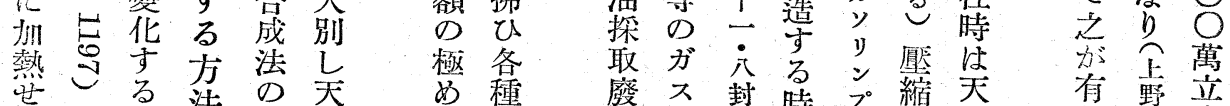

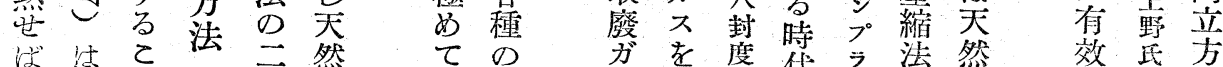

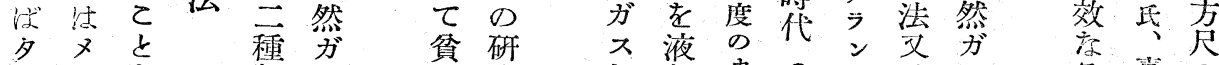

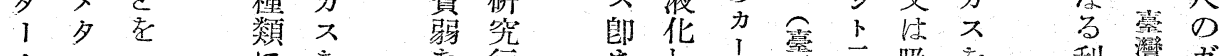

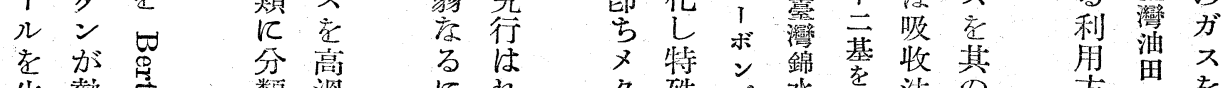

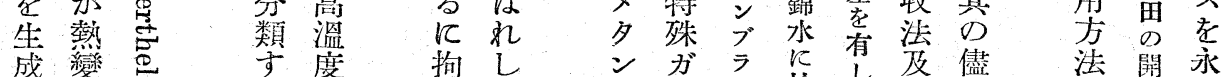

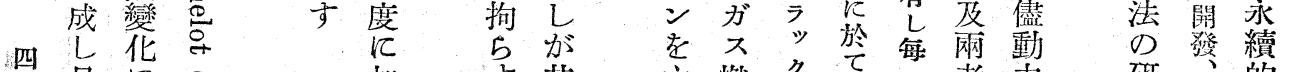

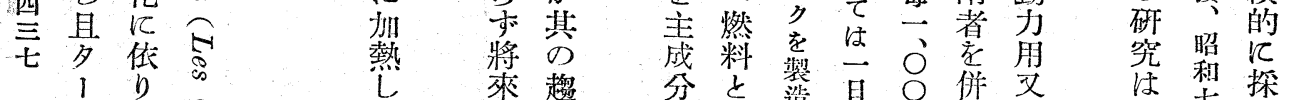

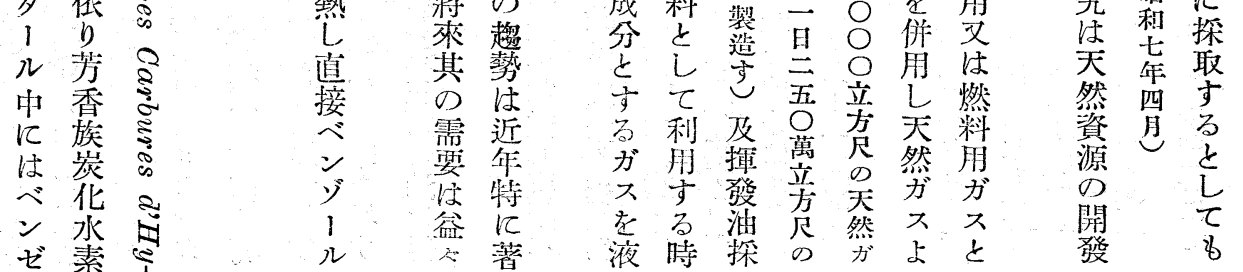




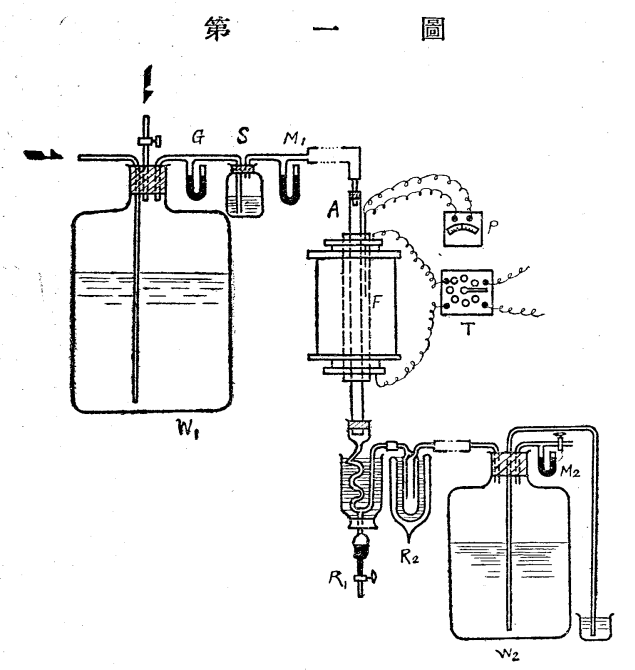

器 度 $\mathrm{M}_{2}, \mathrm{~W}_{2}$ 梥八ス澾料ン任

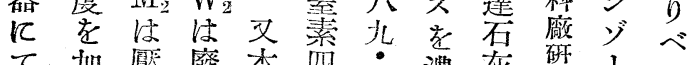

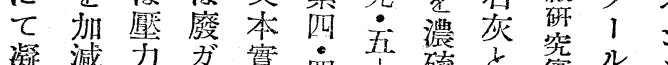

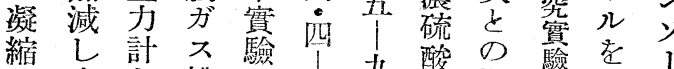

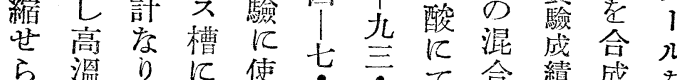

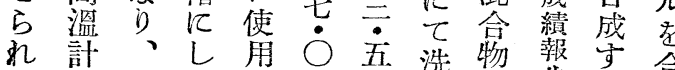

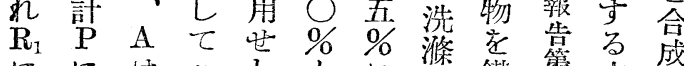

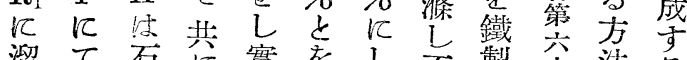

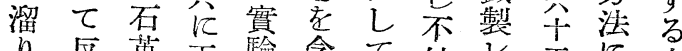

廢應英正驗含て純し五に方

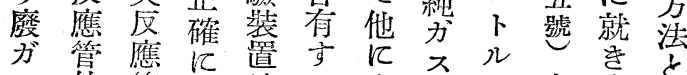

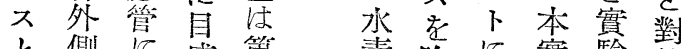

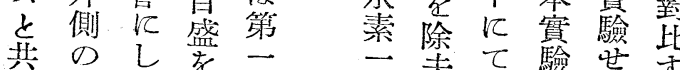

に浼て施圖牭去志驗せ

散度電皆に四屴

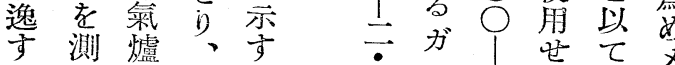

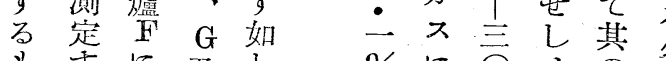

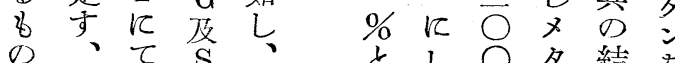

は生加は圖酸し度名繶

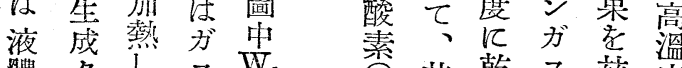

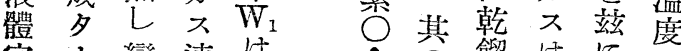

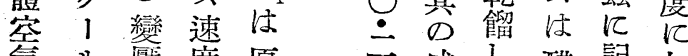

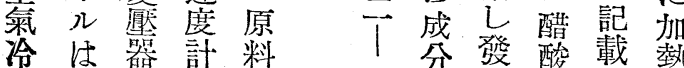

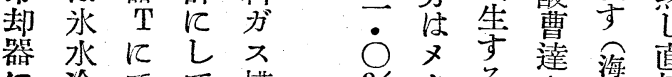

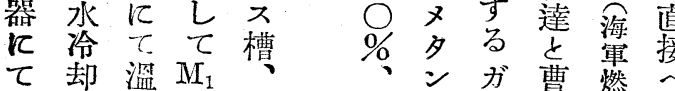

た覅八英不重等导 、

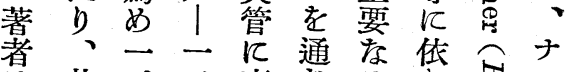

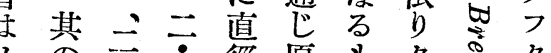

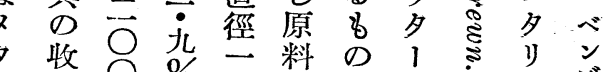

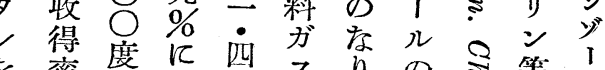

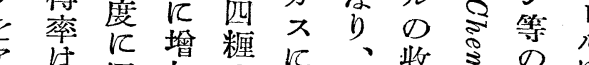

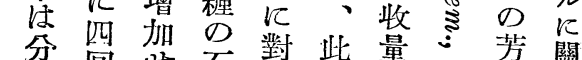
解包せ石姜等量。季關

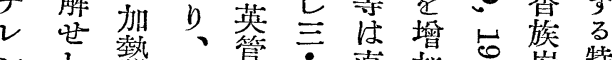

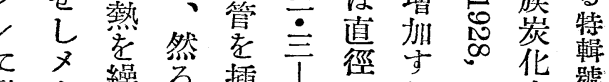

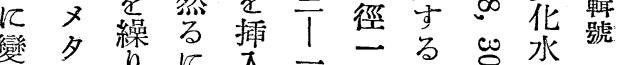
化

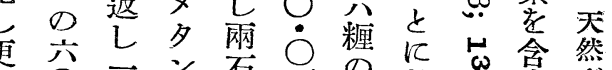
に

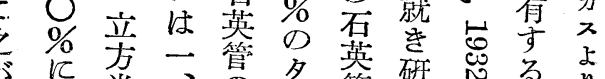
相米品多管研岕方占 當

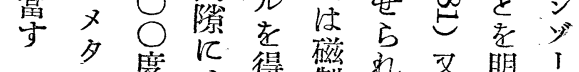

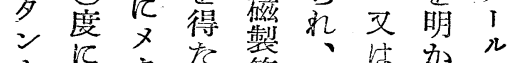
上江多存管、は加兄 り於ン学安就引に合

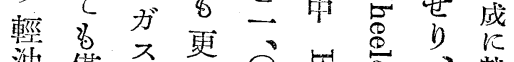

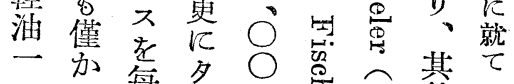

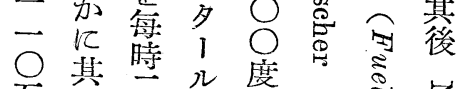

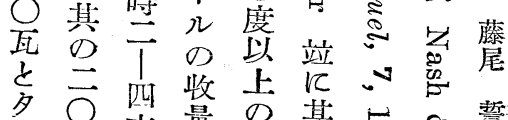
1 立量亭其它 \&

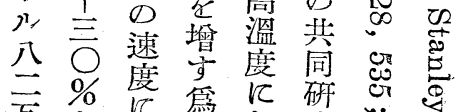

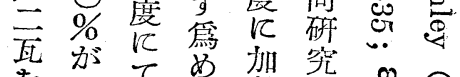
得應通磨熱省心仓 總㣹

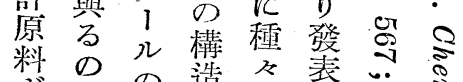
分乡 の造名表心

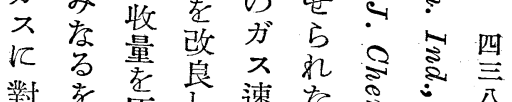
對妾原良速た产公 背料直度方研点

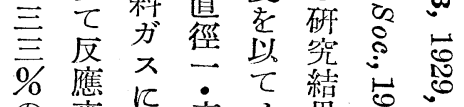

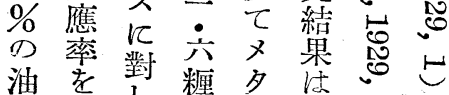

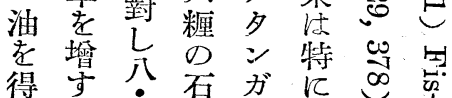




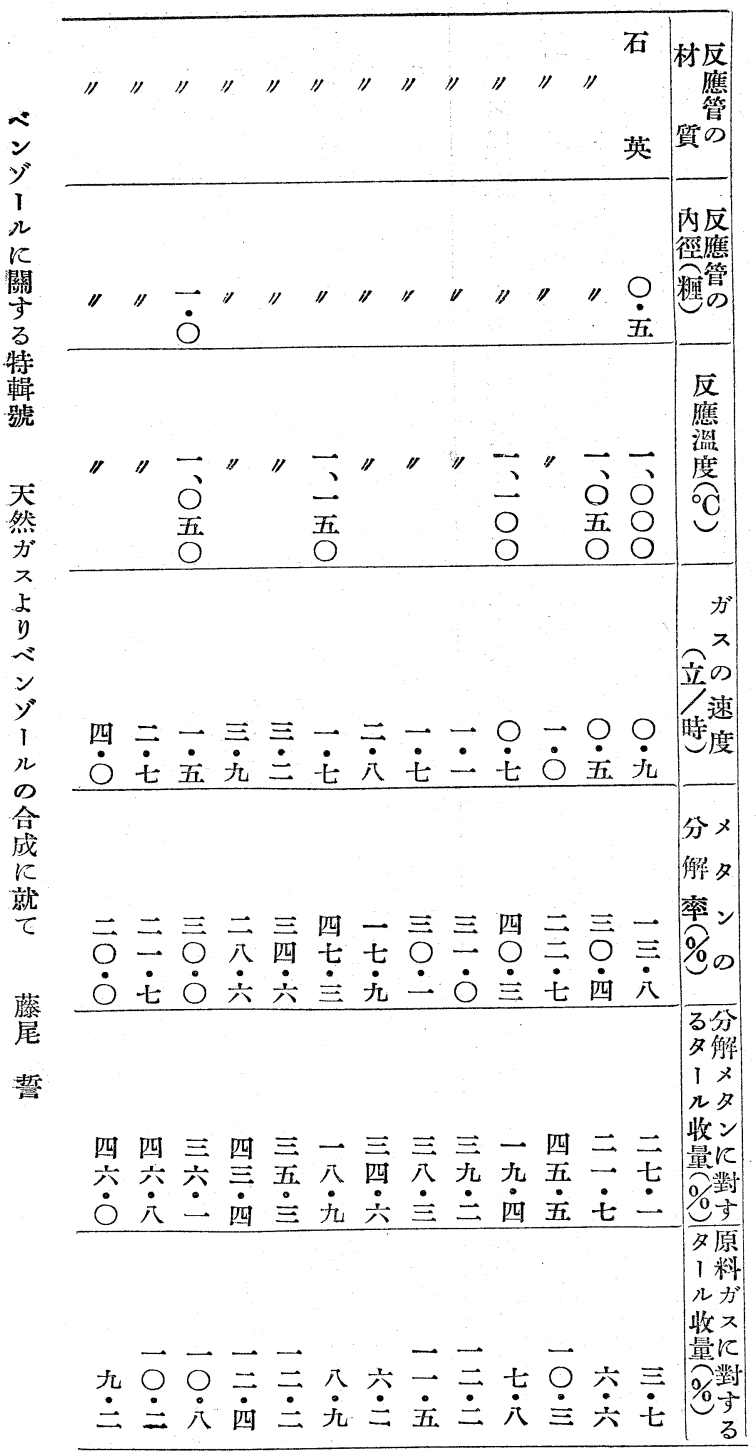

四ば然にし度加スすて夕高か

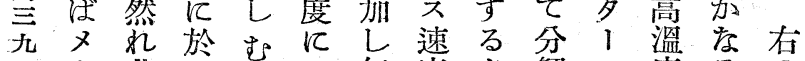

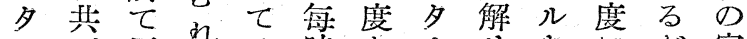

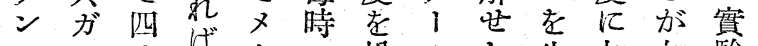
の 六壮夕一增ルし生加如驗 分速\%方立于の邓咸槷く結

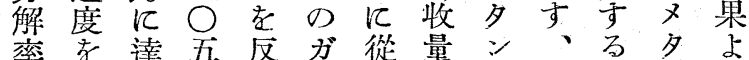
懀专 $\bigcirc$ 應 減妟、度岕速增分對し注を明
糎 石 其 $レ$ べ凝 の 英 先 の ンン本 縮 磁管 づ容其ゼ裝 せ 製に窒積他ン置 ら

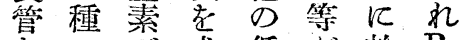
范唯求低が於 $R_{2}$ 二のスめ級散 $て$ 第 $う$ ガ 成炭逸は溜 $=$ 韋速舍泶る成 表江蹎析類凝 1 表加て 內を市縮 熱通の成液包 熱已空哭化收分 × 其夕氣り混守解

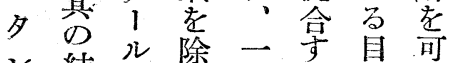
ン結心整方名的成 上果生芭斯をを防 り石盛後々 以步 得英量後乙㢃方 ら管 测記得驗唯自 万渎 $又$ 終

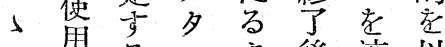
夕角るンタ後液以

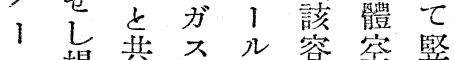
ル場学をは㗊栽式 收合反夫妾に招

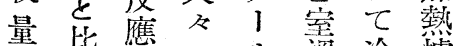
踥管一儿溫冷爐

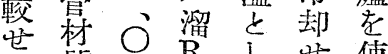
b 䀸 $\bigcirc R_{1}$ 巳 使 、监 $\bigcirc$ 放り、捅

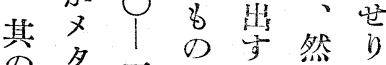
の多古然、 實方二共染に旦 驗疑五共不斯反 結紗 $\bigcirc$ 科をく應 仕化度量吕し廐

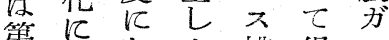
第影加夕槽得 ス

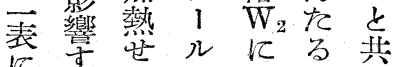
示名当生於凝に せを内成字縮多 万徑量赫液量 がんりを分中の

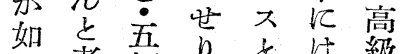
考糎りと級 几箸混多崖 內 - 合量化 徑宁然学素 - 糎势七特 後 チ: に 


\begin{tabular}{|c|c|c|}
\hline $\begin{array}{l}\text { 溜 } \\
\stackrel{\text { 分 }}{\%}\end{array}$ & 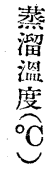 & $\begin{array}{l}\text { 溜 } \\
\text { 分 } \\
\text { 番 } \\
\text { 號 }\end{array}$ \\
\hline 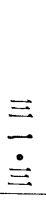 & $\begin{array}{l}\text { 六 } \\
\text { l } \\
\text { 公 } \\
\text { 五 }\end{array}$ & 一 \\
\hline$\doteq$ & $\begin{array}{l}\text { 公 } \\
\frac{1}{1} \\
\\
0\end{array}$ & 二 \\
\hline $\begin{array}{l}\text { 辛 } \\
\text { 亲 }\end{array}$ & $\begin{array}{l}\vec{\lambda} \\
0 \\
1 \\
\equiv \\
0\end{array}$ & $\equiv$ \\
\hline $\begin{array}{l}\text { 竞 } \\
\dot{0}\end{array}$ & $\begin{array}{l}\text { 三 } \\
\text { 三 } \\
\text { 以 } \\
\text { 上 }\end{array}$ & 四 \\
\hline
\end{tabular}

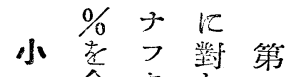

含 夕 ᄂ

以

以

京\%柱

結 \% 亭純

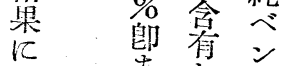

低占垈方

水

仿

然

は

离
應にせた○時 ス

せ對反壮り度夕、に原 しし應ガ、に I 對料

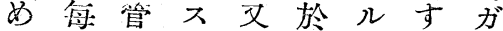
得時材速反てのるス 第た 三質度應は收最に

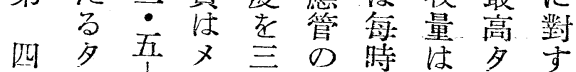
表云分多丙二良主る

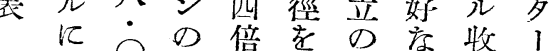
就熱と大時る量 ×を羊變せと约をの 夕其严化る 学又得收 の无に時ば—能る量

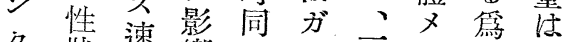

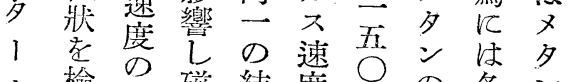
儿檢時磁結度度分备蕰

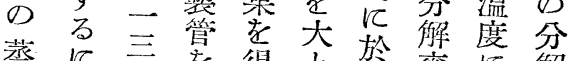
蒸江言变得亡於率に解

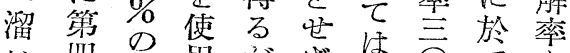
性四多用がざ施てて 表多如礼聚\%適分

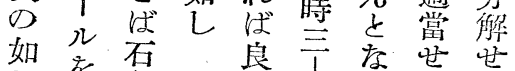

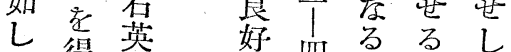

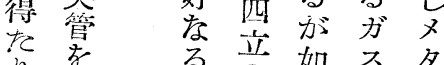
b专咅如 万为 使多時き速 方 斯整水最及鹰老對

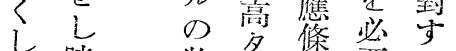
七時收多件要る 溫に 量必它多

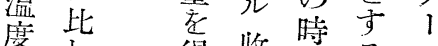
度L得㹈多る儿 一x ○夕就考儿学收 五 ン ざ示の明量 $\bigcirc$ 万人收吕它 度分流量に白 售解 明原量 し 相 時率贺料聚乙翡 二苂に无に、積 立多云澾可考 の゙ ル て、對吉成
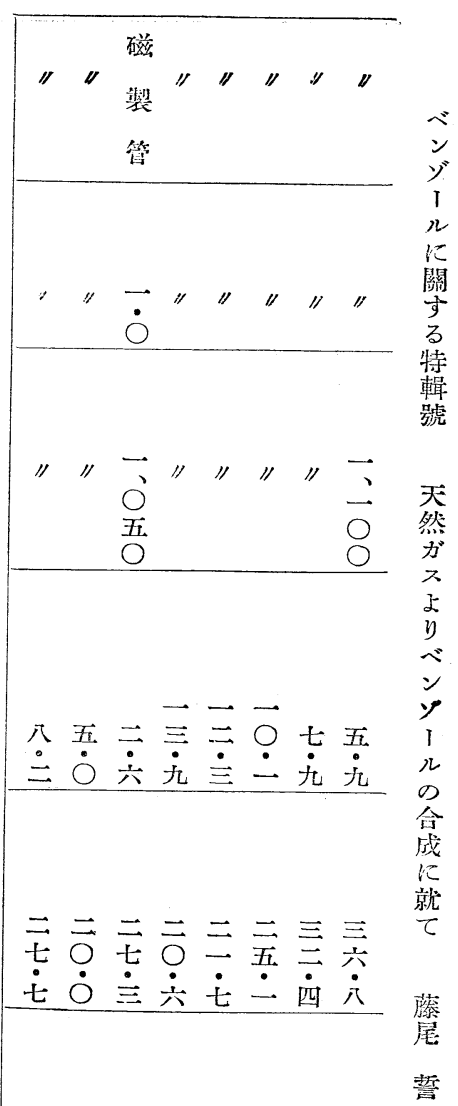

四五四四三三三二

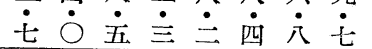

\section{三 $\overrightarrow{0} \equiv$ 八九元

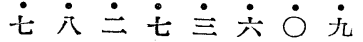

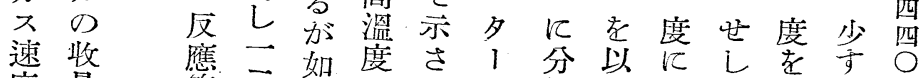

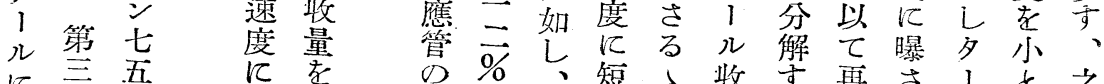

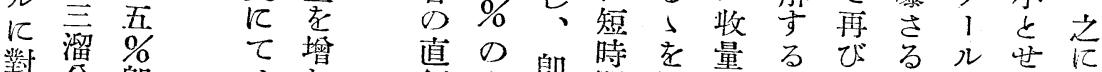
對師界 乙中方名原

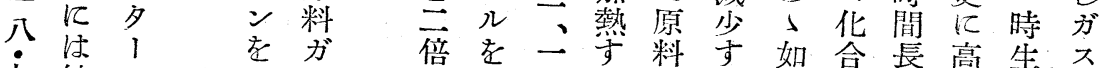

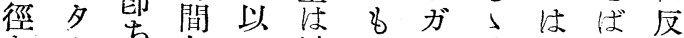
定 15 加て 減 の

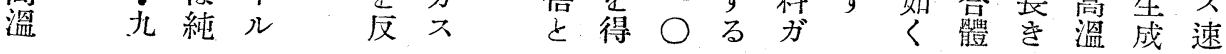


號九十三百第

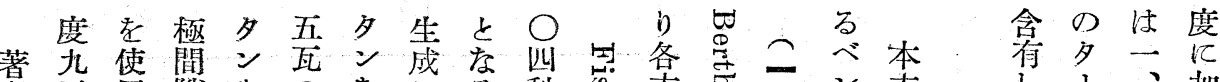

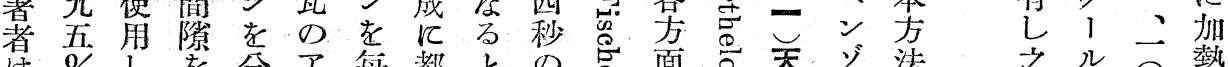

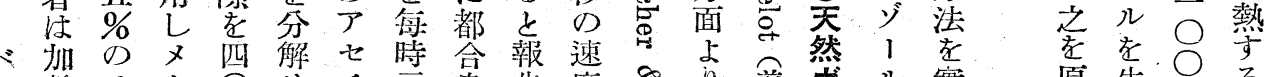

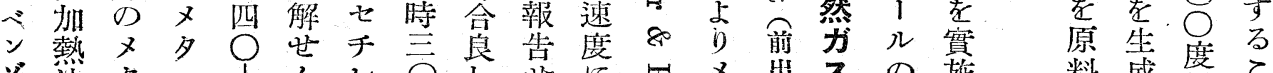

染タ

几 依 ガ 出

關

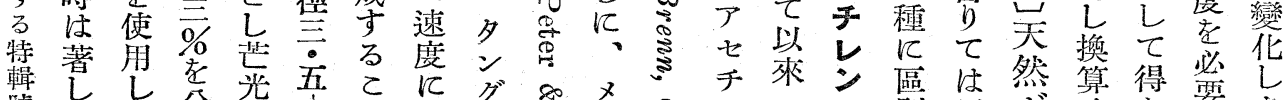

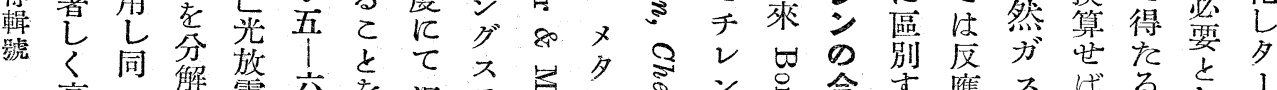

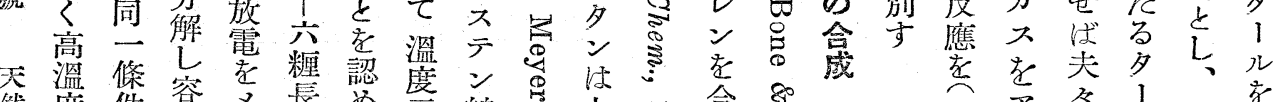

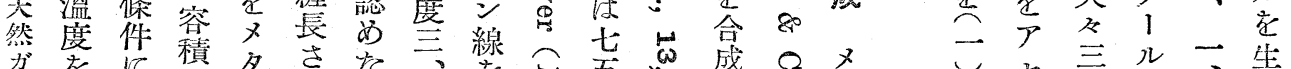

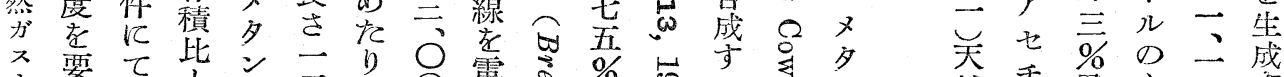

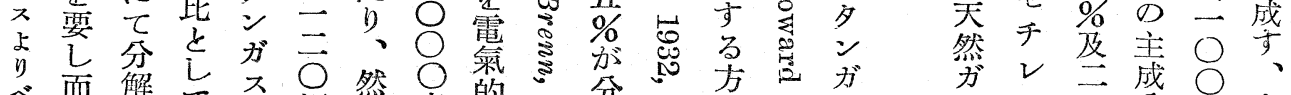

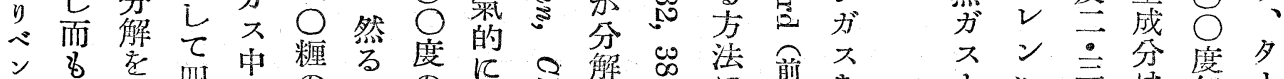

y 8 斯 行 四

1 斯方

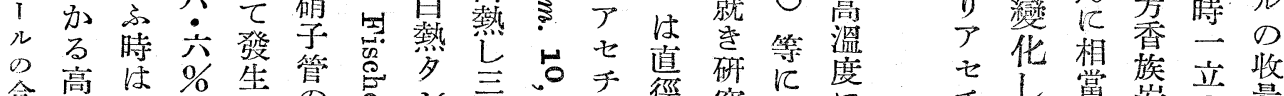

盒溫

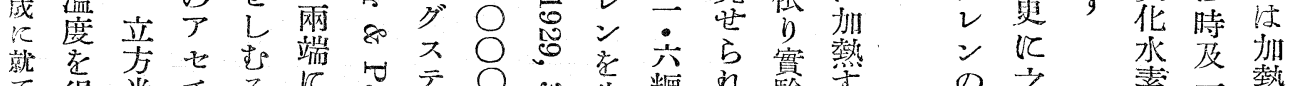

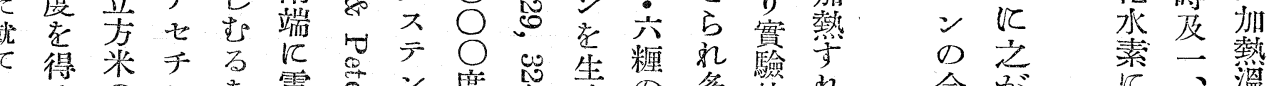

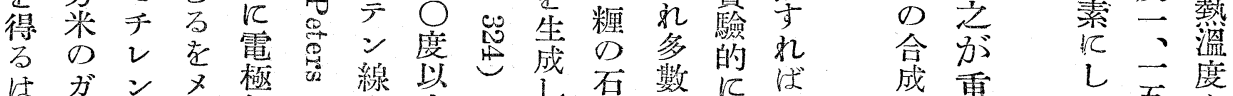

藤實 ス

際 $\begin{aligned} & b \\ & b\end{aligned}$

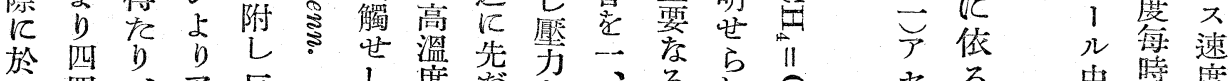

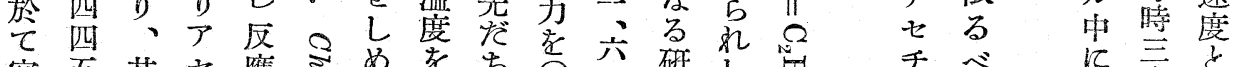
容五其七應 写

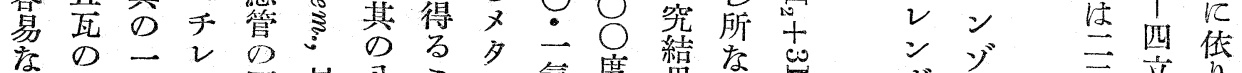

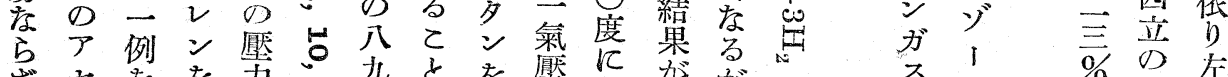
ざせ 宗 を 劣

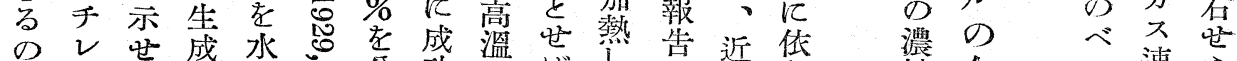

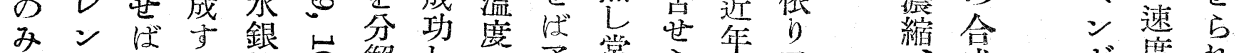

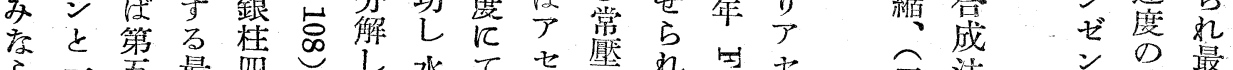

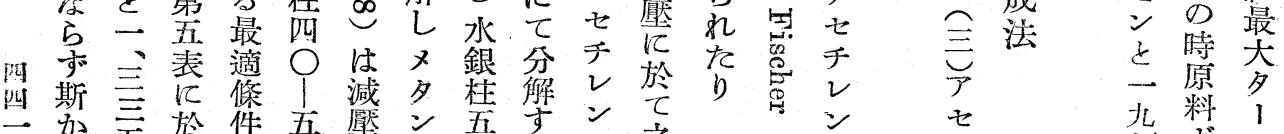
る 五 於 件五

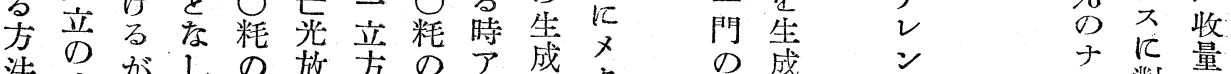

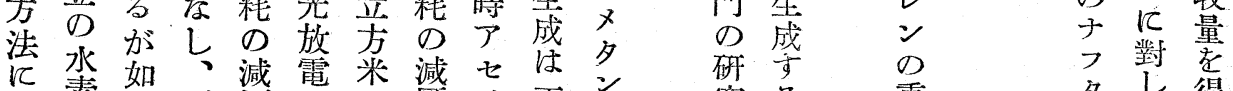

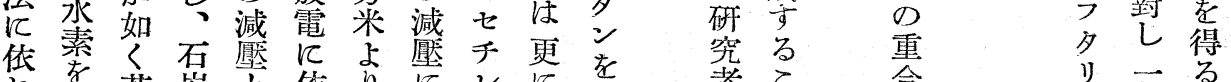

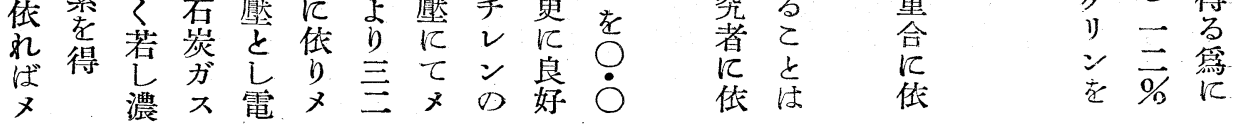




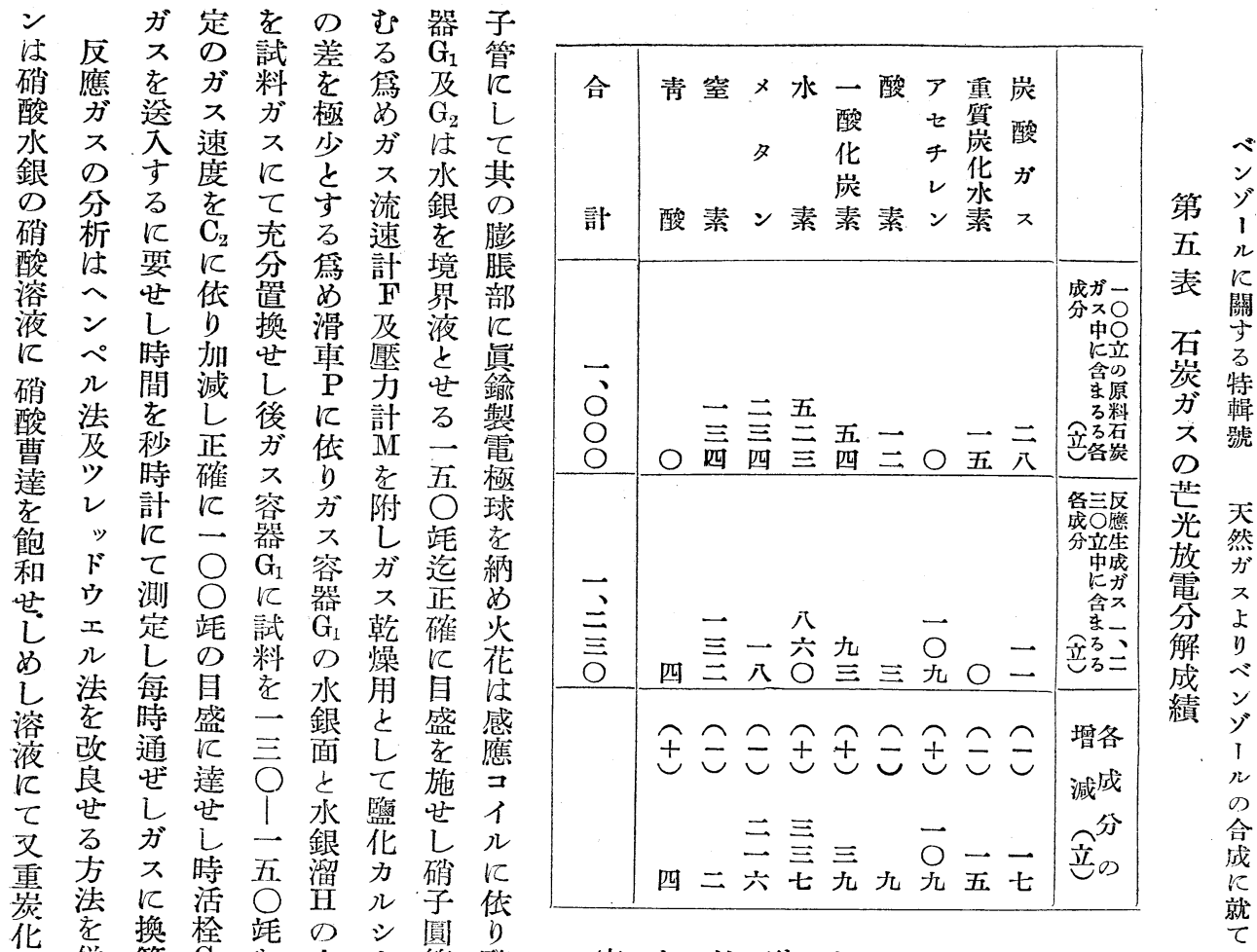

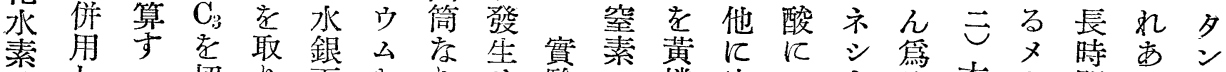

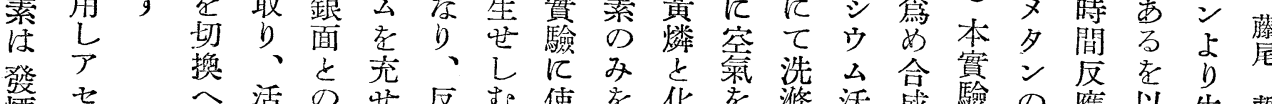

煙 $气$ 活

硫于栓差る應る用混合混せ度せ分圈て成

酸レ 應 $\mathrm{C}_{1}$ を $\mathrm{U}$ 家こ合世合るとる

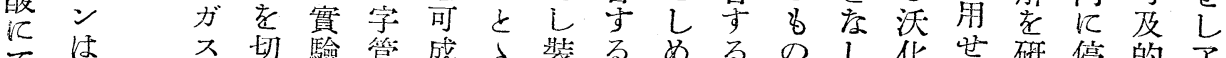

ス 切驗管成子裝るめるのし化骂研停的了

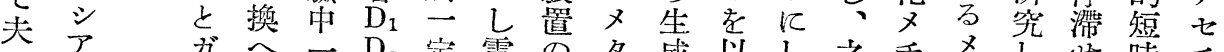

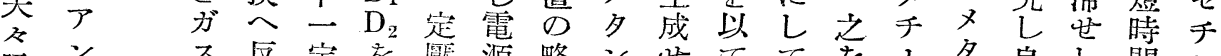

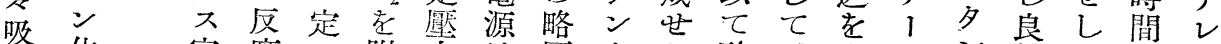

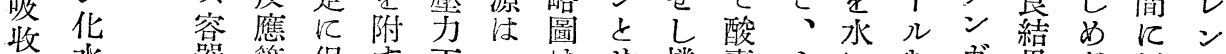

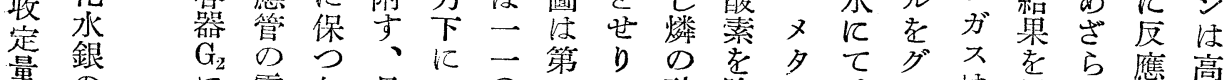

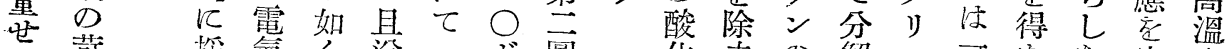

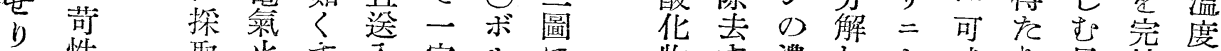

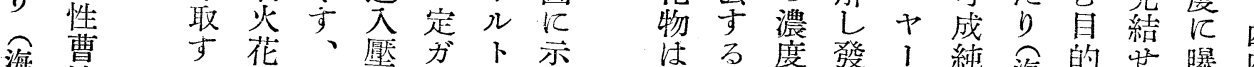

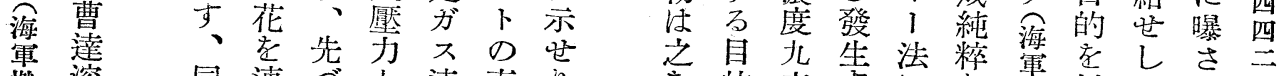

雪溶同連亏゙と速㨁り

料液時續全反度流、

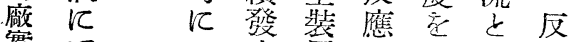

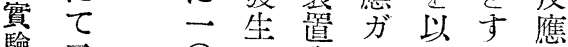

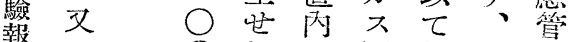

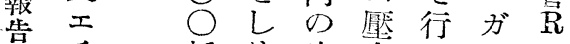

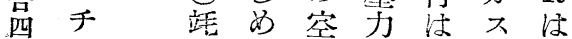

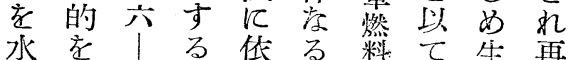

に以九ガり㢳電成び

溶て八スメの研集分分

解 含\%をチを究火原解

せ有に發儿使筶花索寺

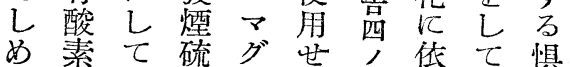



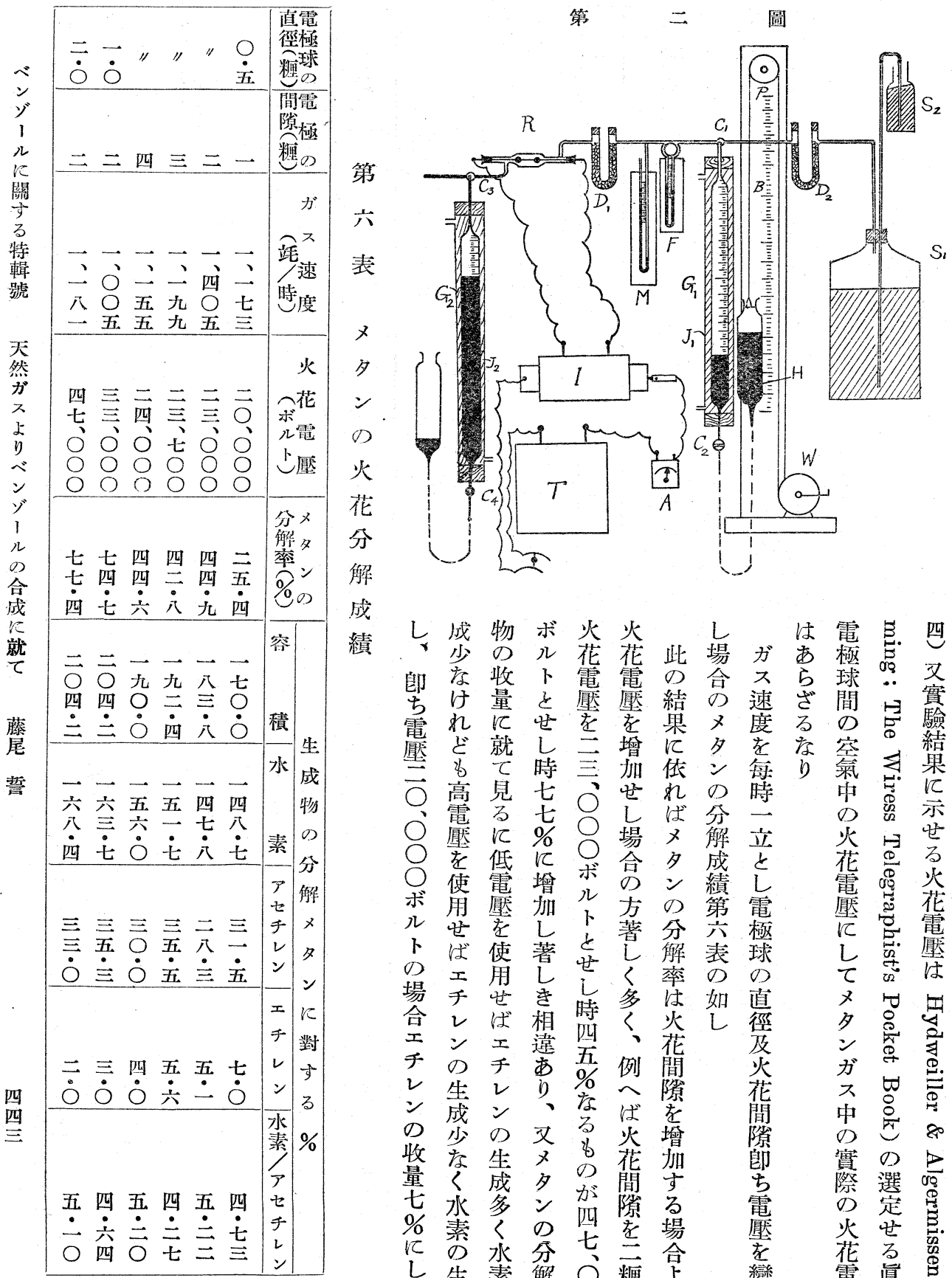

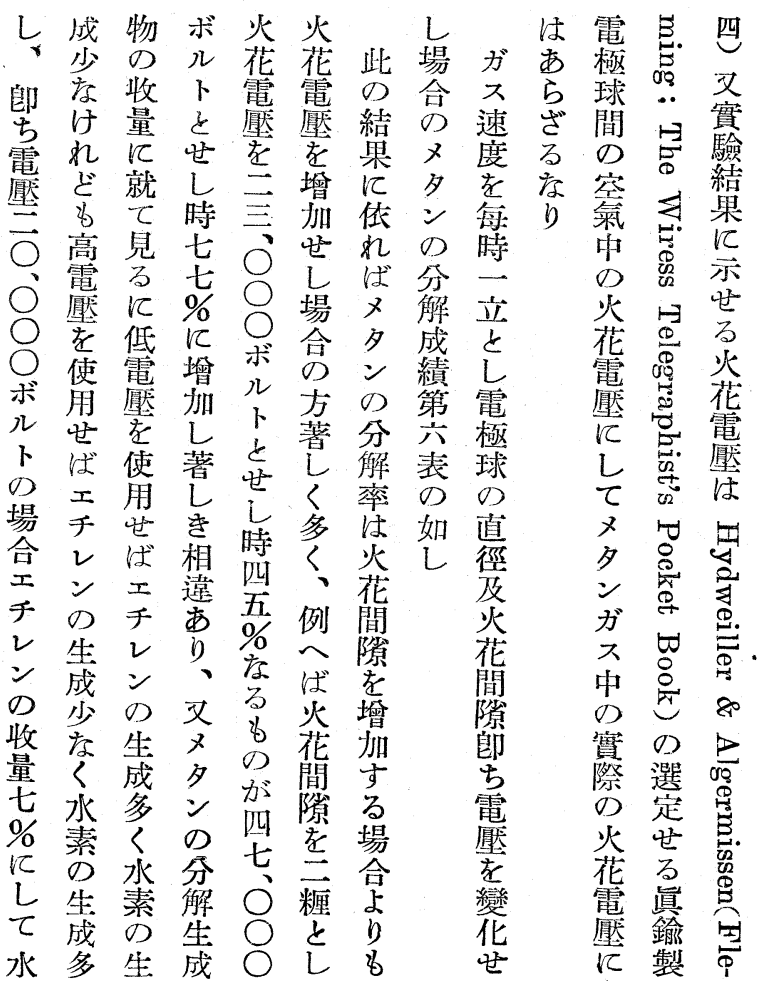


月四年九和 昭

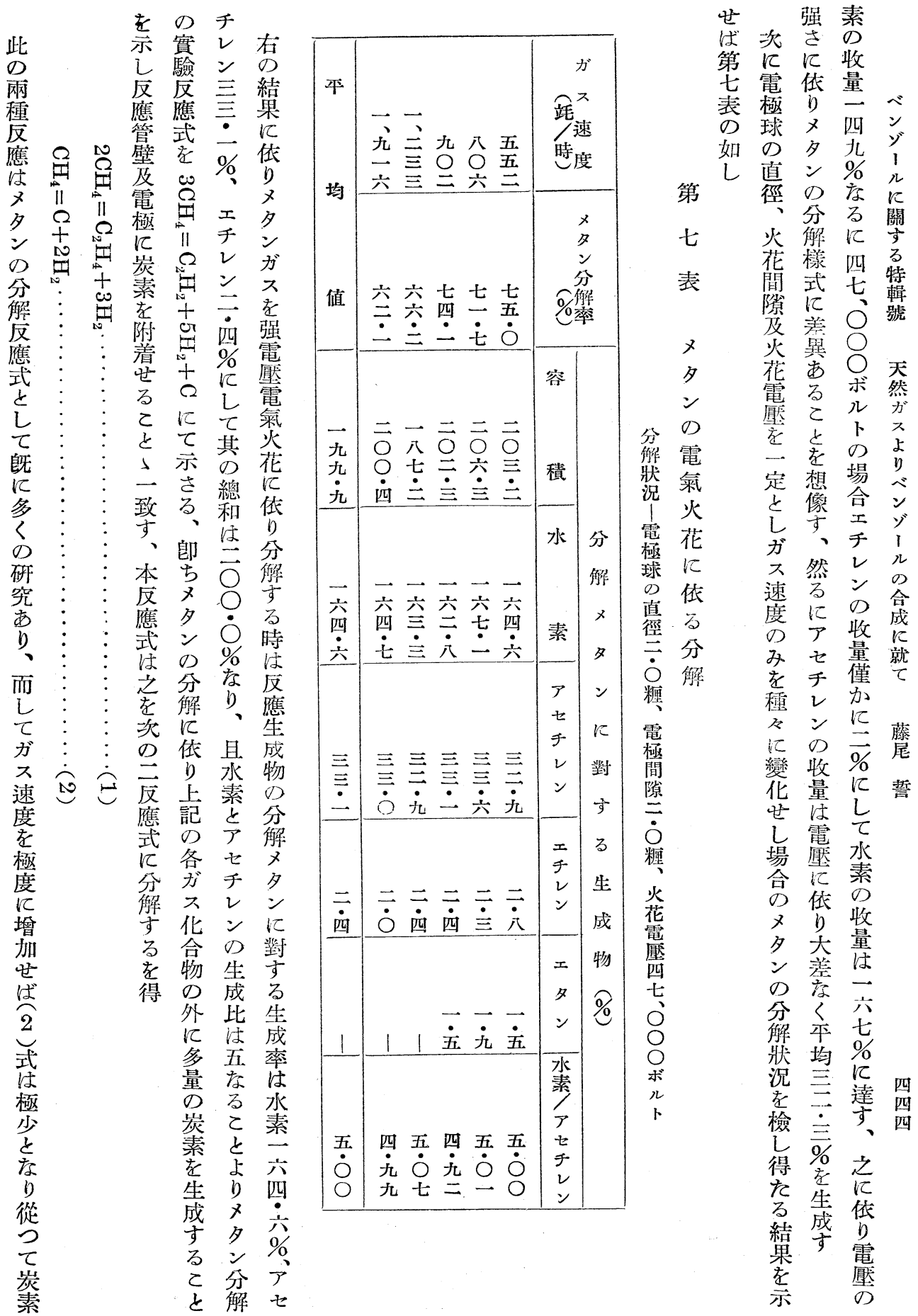




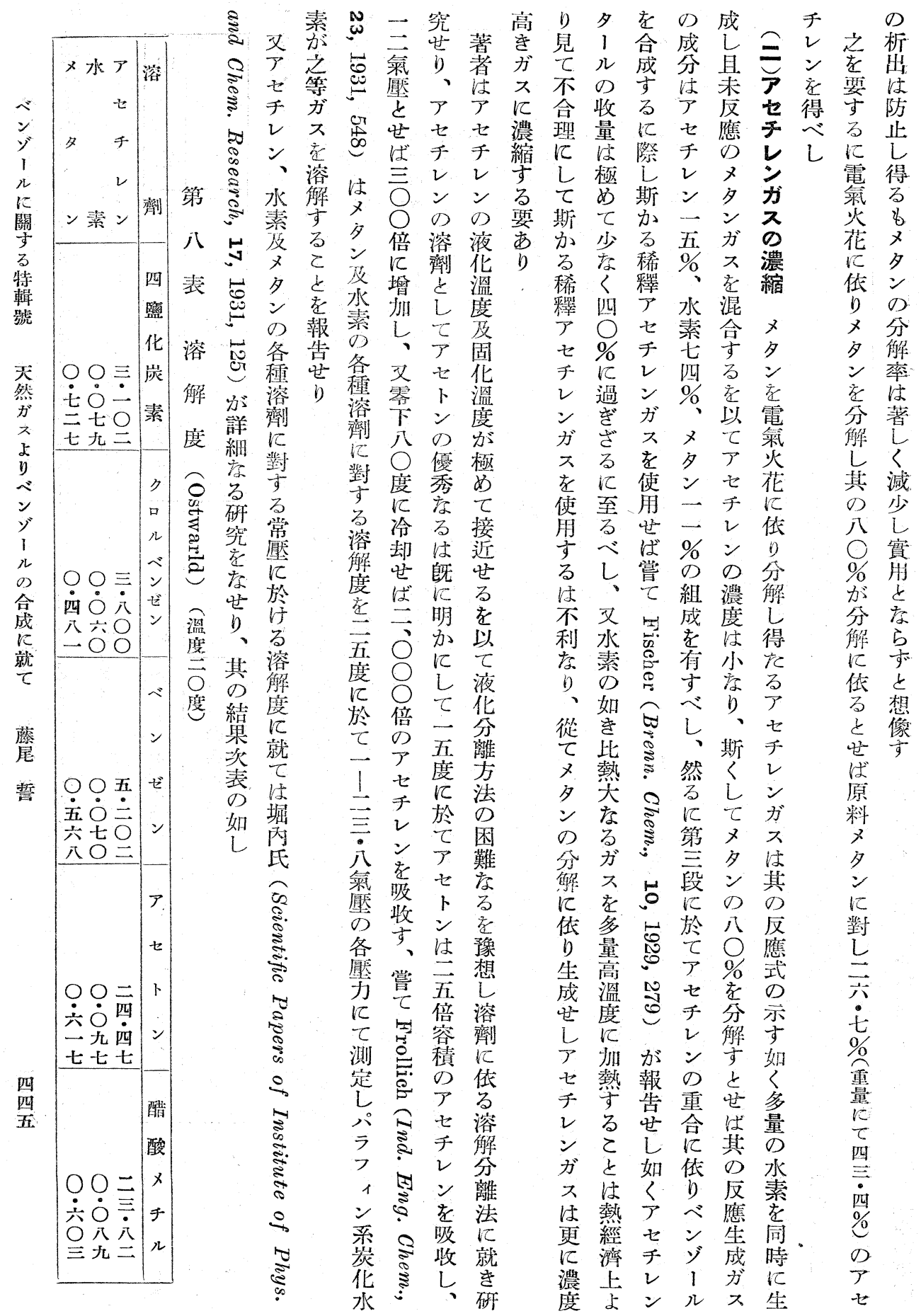




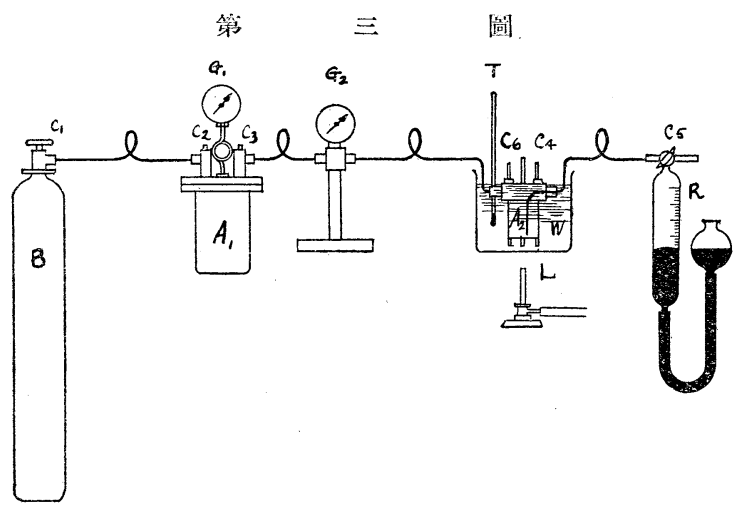

世学宁

ガガ军にの充にレ好先べチ

ス常姇浸活分一先又ン本なな、

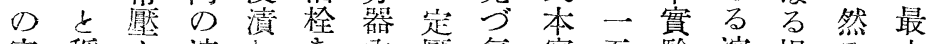

容㷏を溶しを内壓氣實五驗溶惧万大

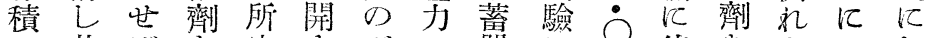

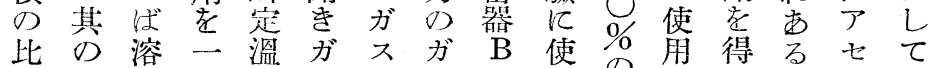

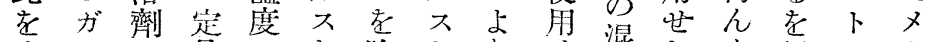

求

め分溶永保加去充原し弇原し元法

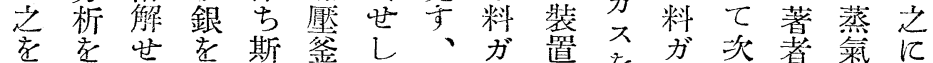

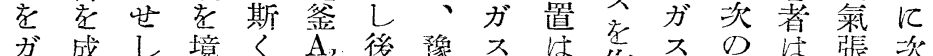

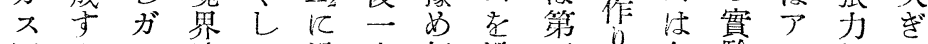

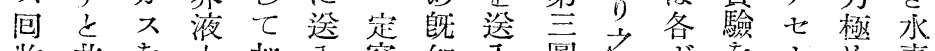

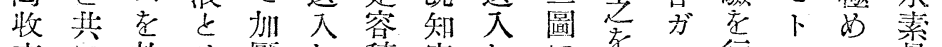

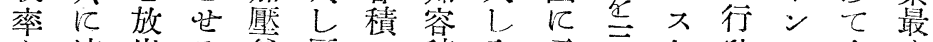

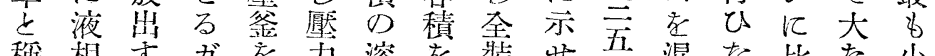

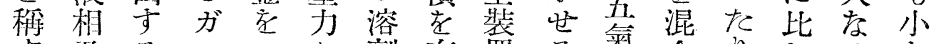

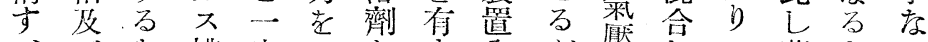

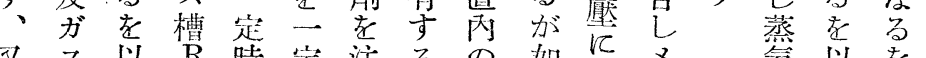

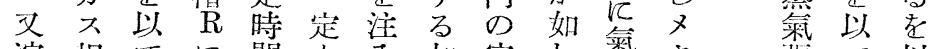

溶相乙に間と大加空し蓄夕裝乙以

劑 の 液取輕 L L 慰氣

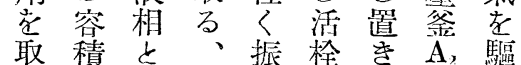

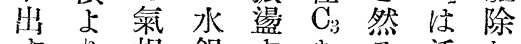
寸 $り$ 相銀す、考了活 L 上一次面、閉 後栓 既 同. 定分老所今゙加 $\mathrm{C}_{4}$ 知 時溶離加定、厴老容 几劑す、減時加釜經積

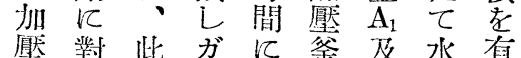

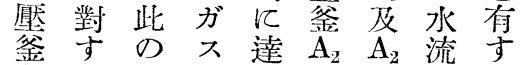
$\mathrm{A}_{2}$ るガ槽すはを术る 中放不內豫連 加 の出をの壮め結プ壓

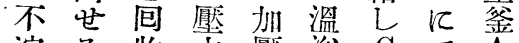

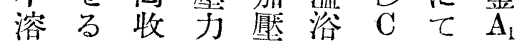

ん濃七

せ 縮 チ

ば得ン

處るの

理疗溶

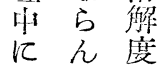

於と注

け度著

る 䆡し

七相

卜 想 違

○像

損 得

蓄ン尛之兄

公更衣斯

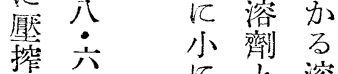
せ \% に穴 る 多水沓元 の素具学隹

古五千的

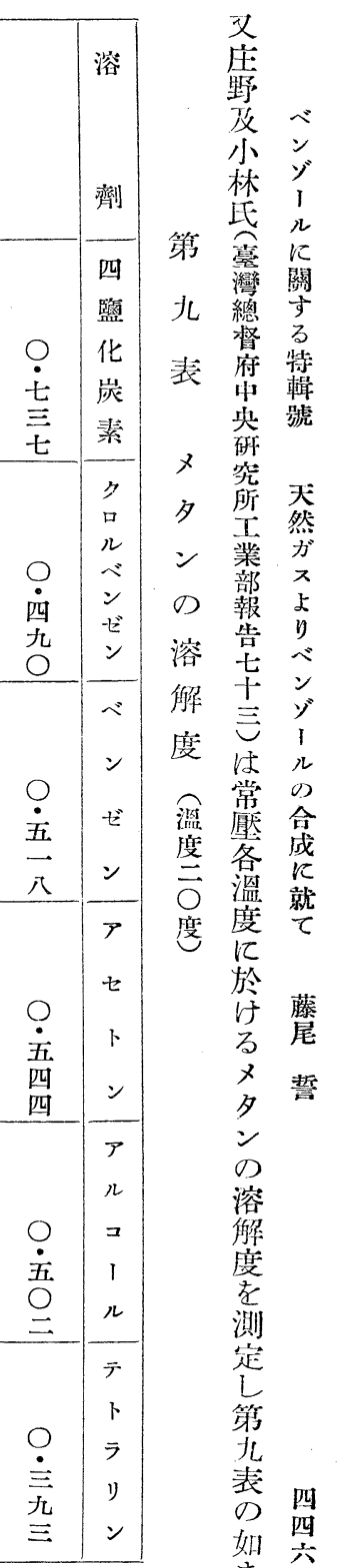

分とアメ 各通結

レンセ多溶覽以果

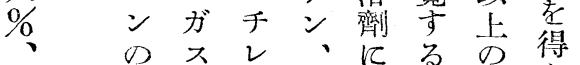

ア吸变ン水對に結㢳 
號九十三百第

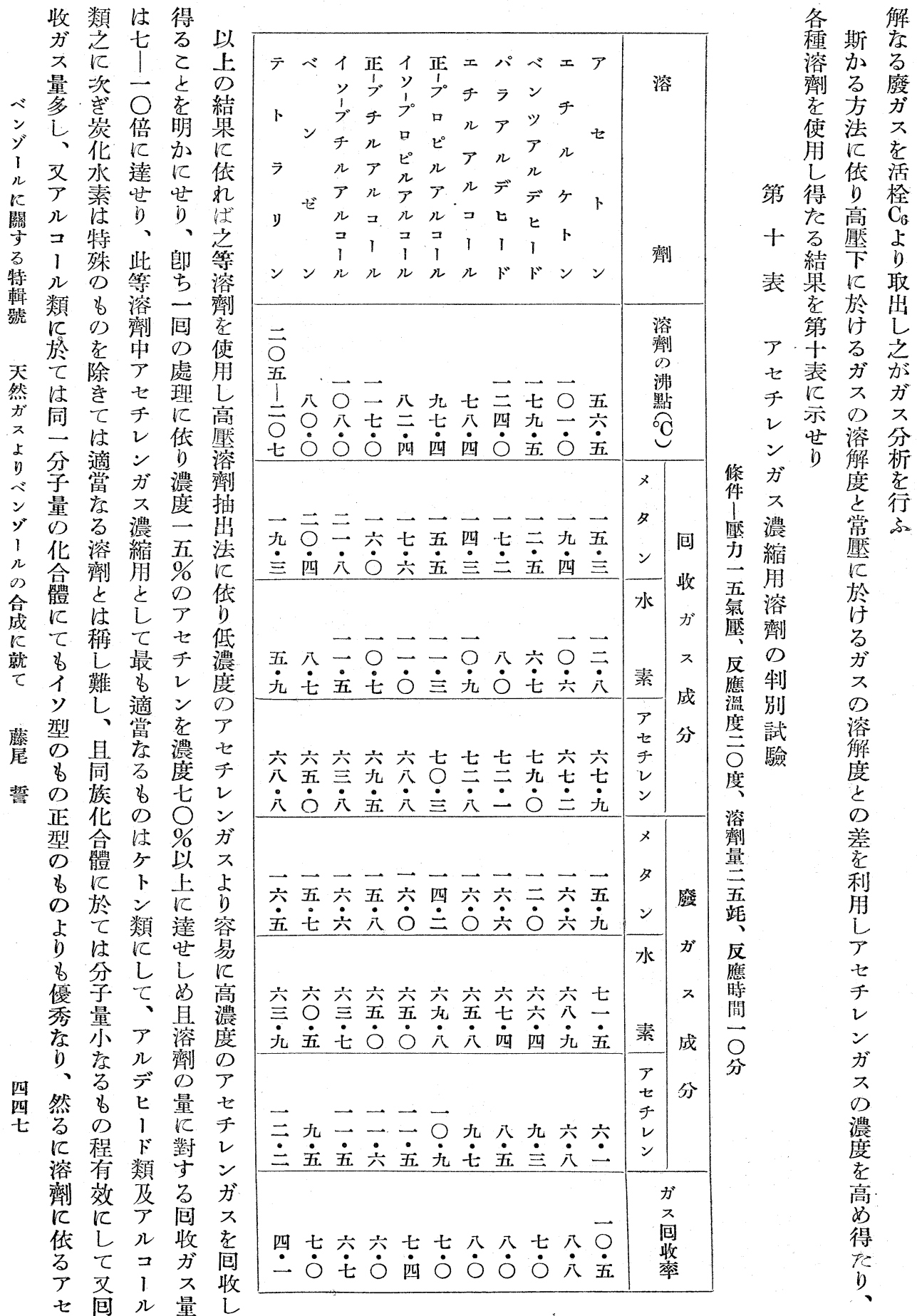


月四年九和昭

度合使度す铉 度厴方角了しめ 少る就零䋨 溶の学れ千下果 劑影有ばレーに の 響利间ン五示 量占收の度す 在厭省蕽於加 五少 竓怘 し 習 、壮レター10 厭ガンンルア

力又濃及的七 のの度水約千

子溶存素—V

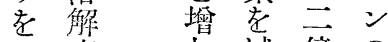
西度 少減倍の 氣增方分綃

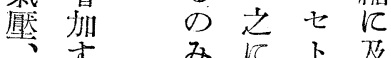

一古疗 反店

五事 らしはす

氣明来废約溫

厴加 ア ガ 一 度

范质 七四心

永我成倍影

氣气゙レ分上響

厚星 ン に

汇回 於る 想

變收包て 、像

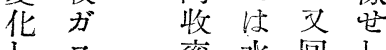

L $又$ 率水问 $L$

成字素收如

七分著及交く

チ杖过多筼

ン如 何 临 ン 成著

ガに L老分 L

ス變》増にて

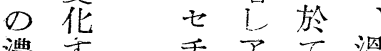

䌉る レ它崖

古加ン于著索

行主方レし低

U決 ス ンく卡

た是のを變す

少濃減化水

る 縮 梠しば 临に、溫ガ

め は郎度

反低艺老の

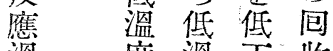

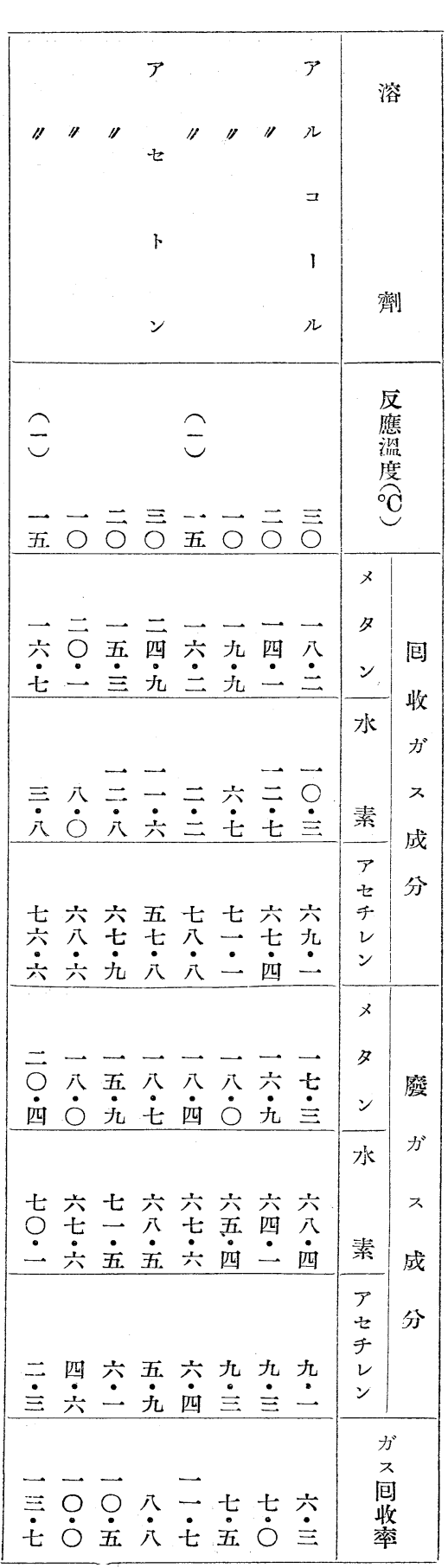

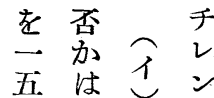

五氣明 艺の

壓加應高 へ

溶溫厴 ン゙

溶ら度 抽

劑ざの 出

第の影法に

十量ば響は關

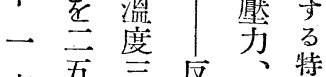

袁 五 靖 反 鷹 溫 輯

儿度㵋度䠋

列度

反定至索反 天

應 せ 零降應然

汹 - 方間

五血机及

度度仿溶心

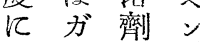

の) 於

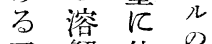

ア解依 合

ル度り 㚜

1 堵響 就

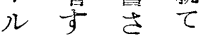

文乙る

๖

卜加之尾

ン店㭱誓

亿想

依共脩

る颗に

ア L 難

七 方

于回 5

レ收ざ

ンガ礼

のス壮

濃 の 文

賽七研

驗于筧 四

行ン老四

り濃

此度

高

蔡生

厴る

力 力 
號九十三百第
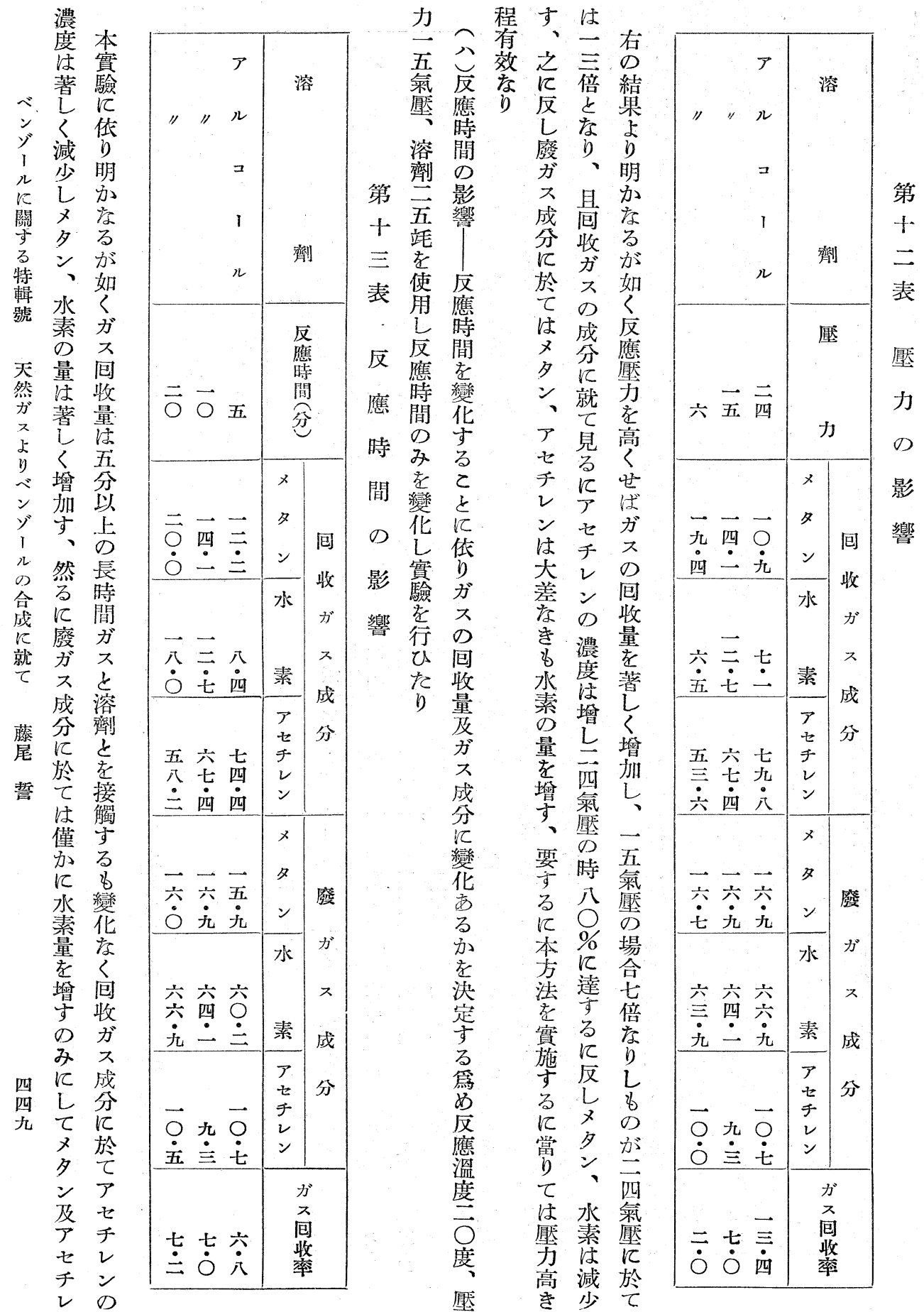


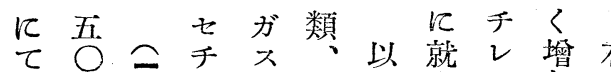

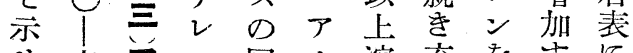

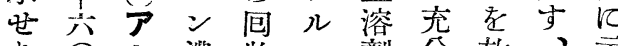

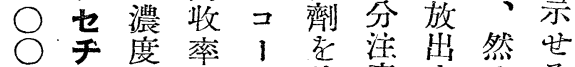

度レ索索儿使意与するる

にン 減良類用㪲るに如

熱の禾好汃しるて廢く

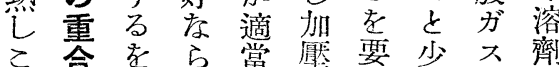

和に以上抽宁质成の

が依て む $し H$

へる特るて法

ン に \& 容に

ゼン注反易依

にン゙意應に方 る

に變 ル 要 間 セ

化の 蜍チ千

せ 合 b ᄂ

乙 成等

と 一 長

哂六具度濃

め六 剩七 法

年 の $\bigcirc$

此

の

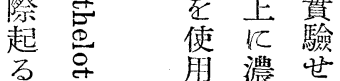

化 名捅濃せ

學 尽 る 筞 結

的㤐時方果

變守字安

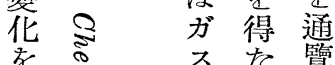

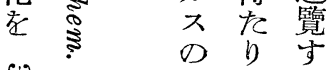

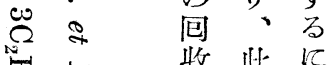

收此溶

11 空 率 0 溶

四山 低嬮

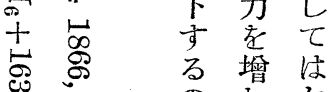

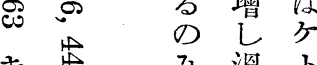

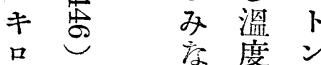

力应 占品 類

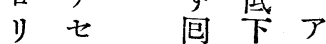

1 チ 收すル

のレガる デ

方ン 不と比

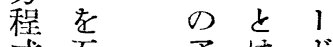

き分量

反学

依於增

るて 加

、惊世

䬦アは

剩レガ

の 量

溶学量

劑減 老

字使水筬

用素る

す考 の

る輞 ね

乙 す

は之和

却就包

乙 溶 收

成 劑 ガ

績 が ス

低 多の

量成

寸存分

る る 伿

定時 於

以度姐穴

て本慰

方它于

法减 レ

菑方

實 る

施吸

る 收 邓

にせ 夕

賞方 方

て

特 素

此注

のア著

點 七 L
滆手收

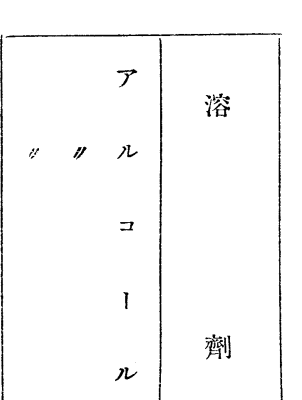

應 㫭さ さ

間 $\asymp$ 量

$\bigcirc$ 絹

分量

$\downarrow \infty$

第 乙 影辠認

ᄂ 影

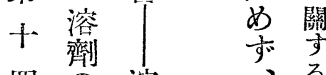

四の溶、る

袁量劑 要特

量方

溶五方泣

溶竓 ガ 本天

劑、方然

五间法

$\infty \begin{array}{lll}\bigcirc \\ \text { 收量 實 }\end{array}$

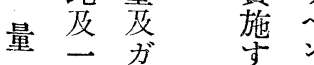

の $\bigcirc$ 万 成

影竓分當心

影江雨合

響變如何成

七孝 反就

實る應

驗 影時

怒響間 藤

行市に笔

ひ る 特

在泟

b走注

決定意

寸 万

る篇要

め L

應時

溫間

度江

度突四

時

厴は

力 却

五

五氣成

\begin{tabular}{l} 
三五 \\
$\dot{0}$ \\
\hline
\end{tabular} 
號九十三百第

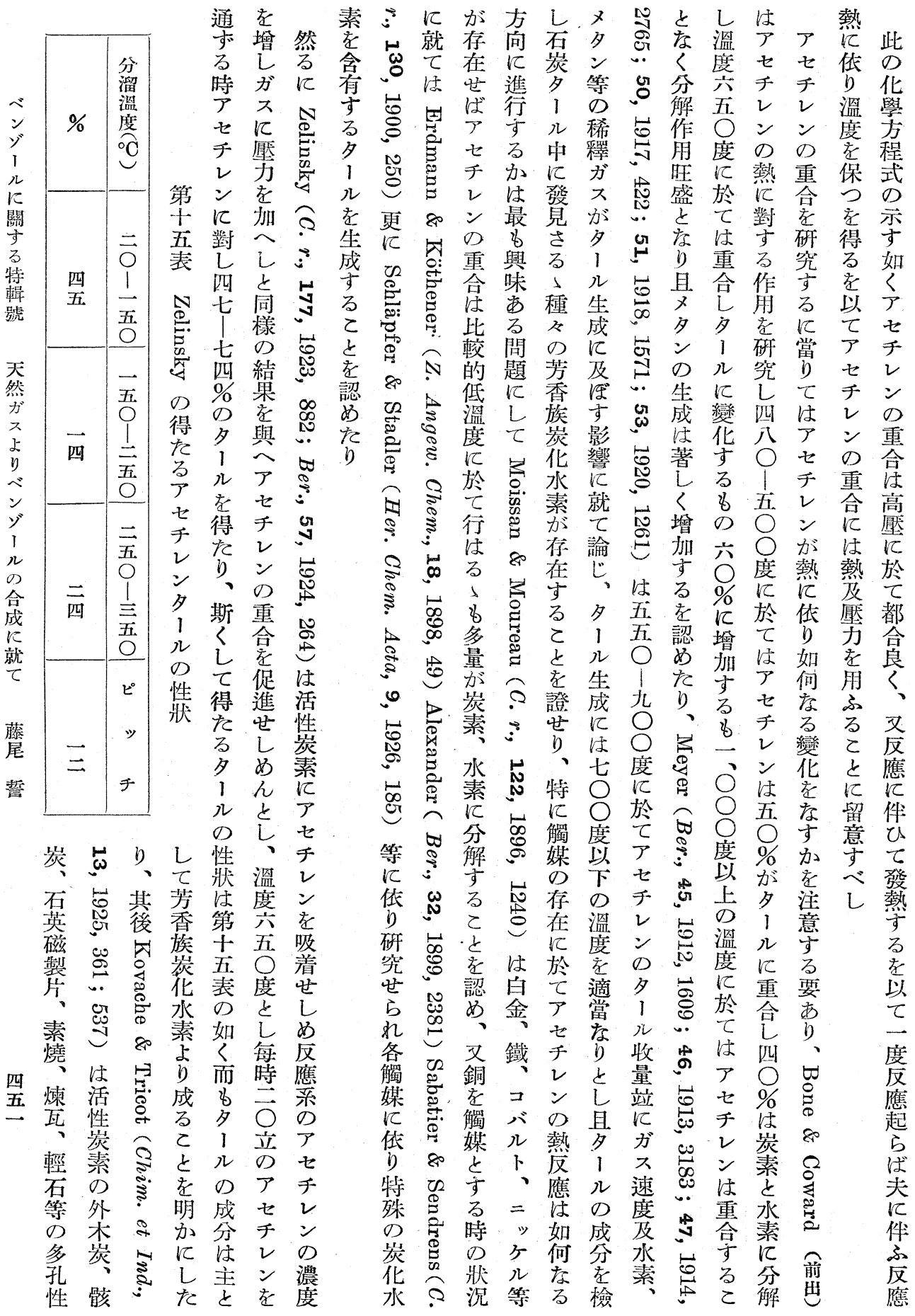


月四年九和 昭
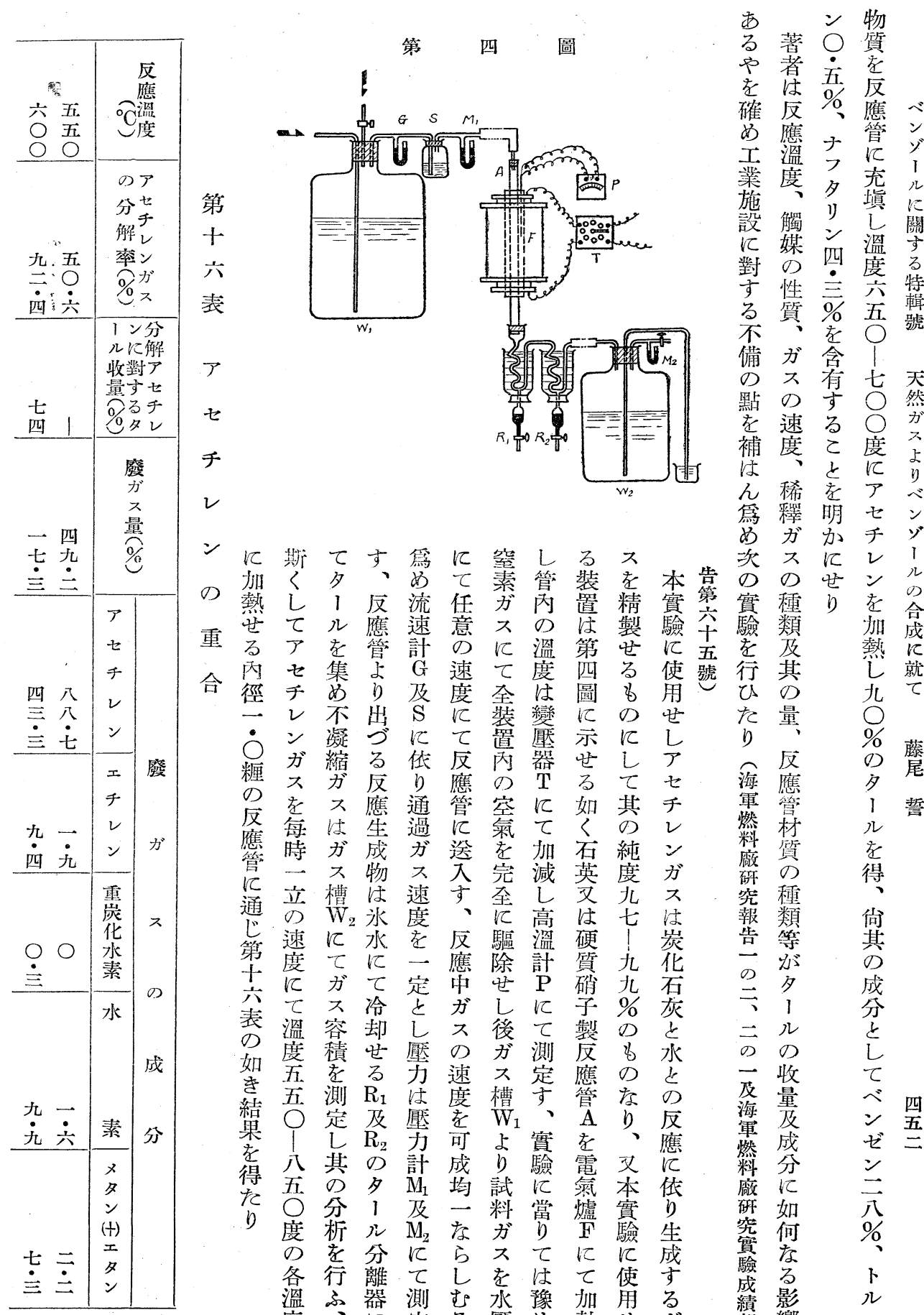

第釋 明 七

め吕吕于

ンに斯てす爵に空しるス

次 $ᄌ$ K 2

加く夕、めて素管裝を本告ののせ

の熱し1反流任分內置精實第實種りを䓃

重芭てル應速意スのは製驗空驗類加喊

る

合內徑

一 レ不出 $\mathrm{S}$ 裝變にのせ た量に

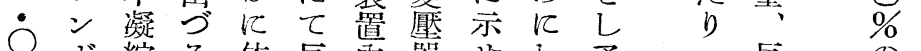

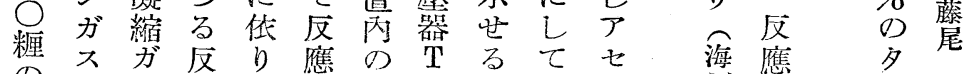

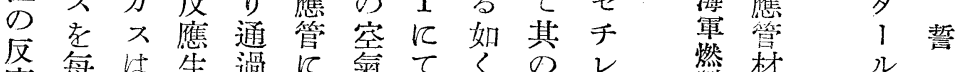

膺每は生過に氣てくのレ燃材ル

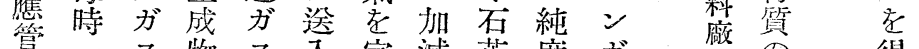

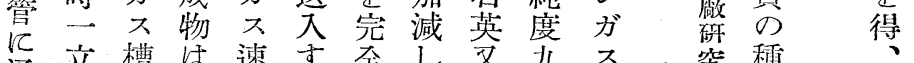

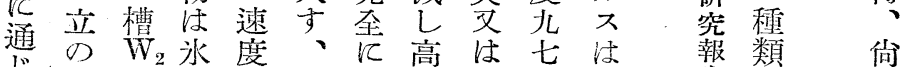

第速に水を反驅溫硬! 炭等等其

度てに二應除計質九化西㣻向

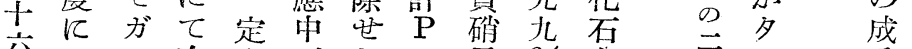

袁て

表溫容却し

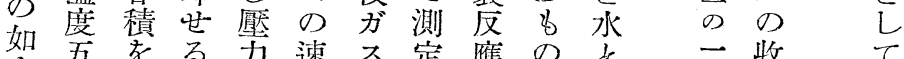

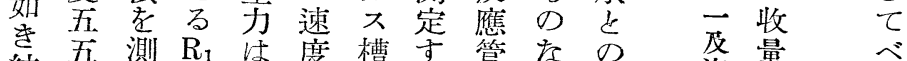

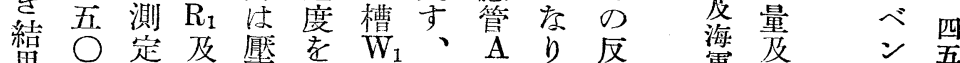

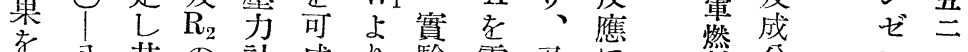

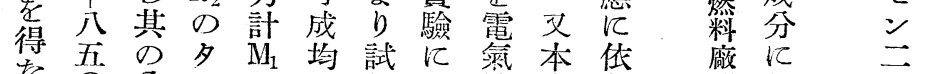

た 分 1 及一料當爐實可研如分

度析心 $\mathrm{M}_{2}$ 小

各行離てししをはて使等驗るる

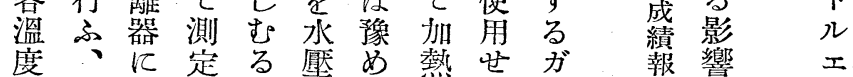




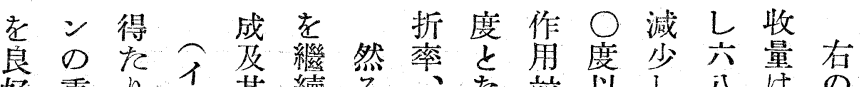

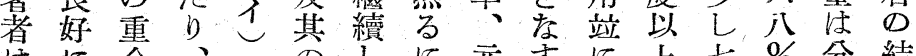

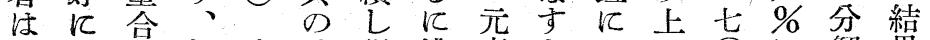

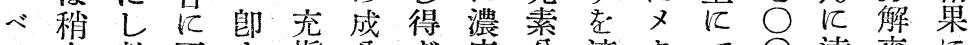
多熱不方填分さ蔗分適夕て 達率に

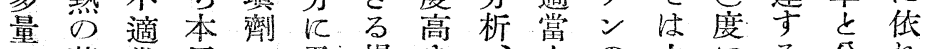

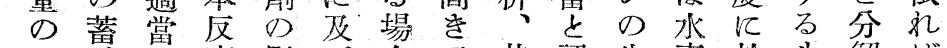

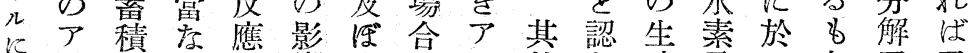

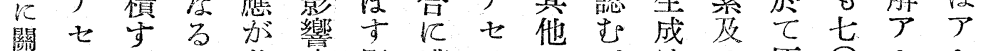

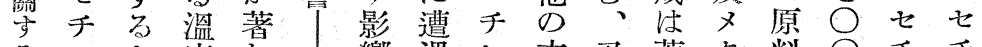
るレを度し響 遇レ方又著夕料○天チ

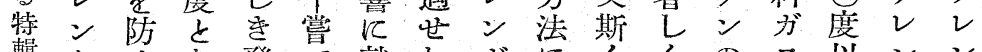

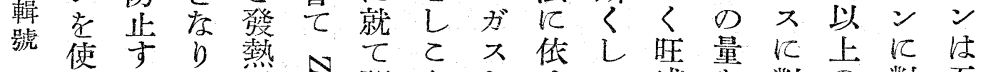

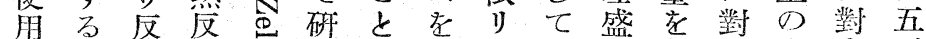

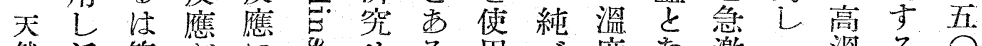

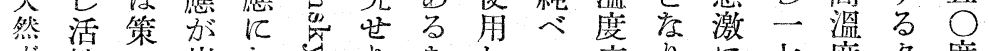

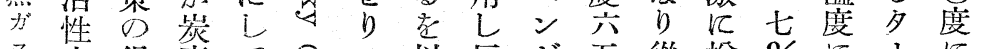

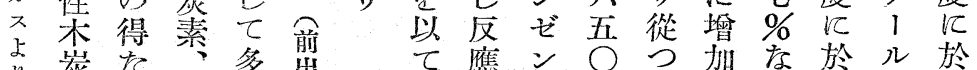

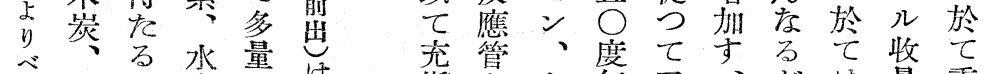

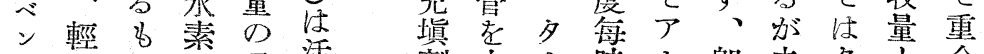

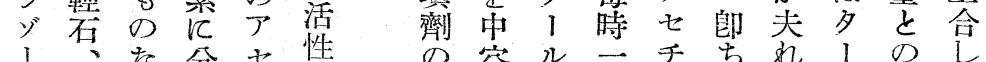

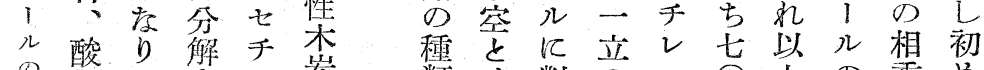

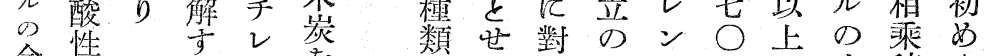

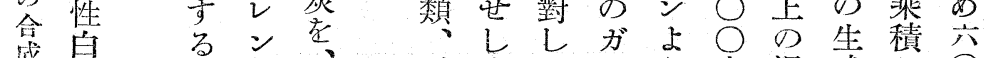

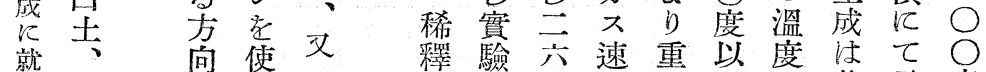
就耐向使又釋驗六速重以度は花示度

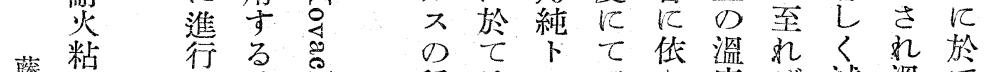

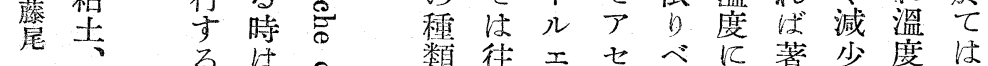
るは霣往エ七べに著少度は

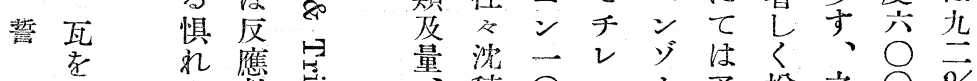

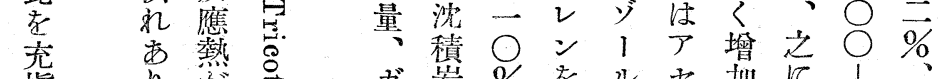

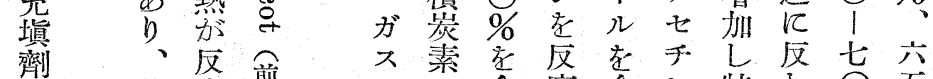

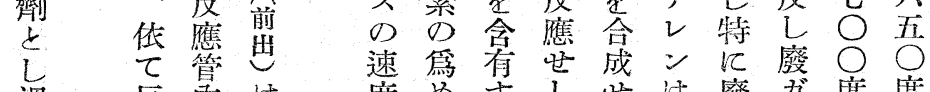

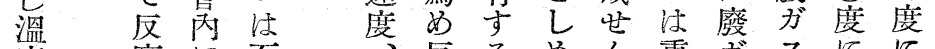

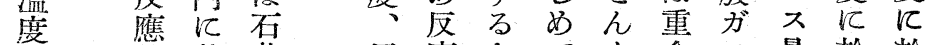

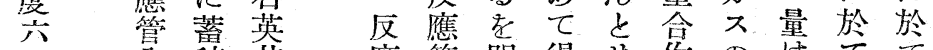
六內積其應管明得出作の在てて ○に他管吕かた汪用成溫最㭱

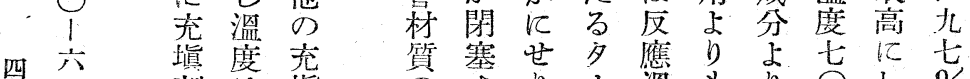

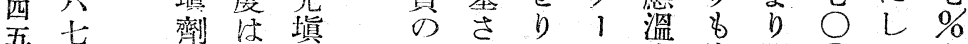
吾苍热讋 度充范 比上使 加熱景用

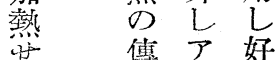
万檤七結 內 放示果 徑散レ在

種礼

類 長

等 時 方間 夕 $\oslash$ 1 連 ル 續 の 實 生 驗
儿度炭明 ○てが 蒙交素古度〉變 溜○水方至七卞 上○素がるチ、 此 1 尔如迄

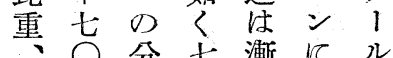
屈○解○次對の

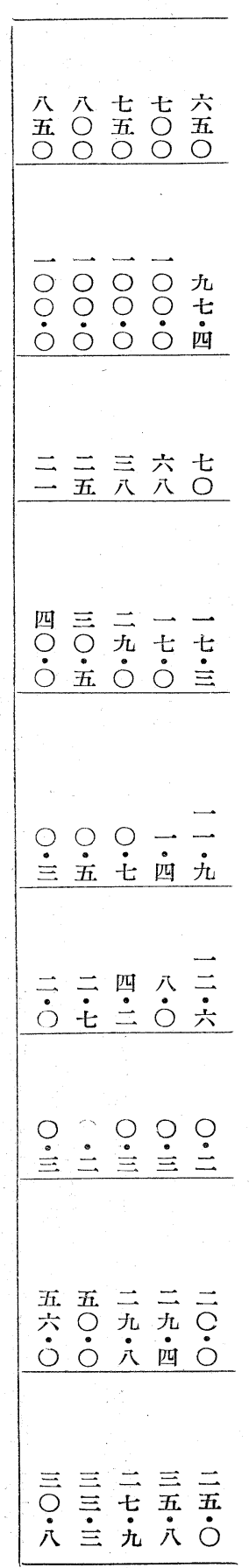




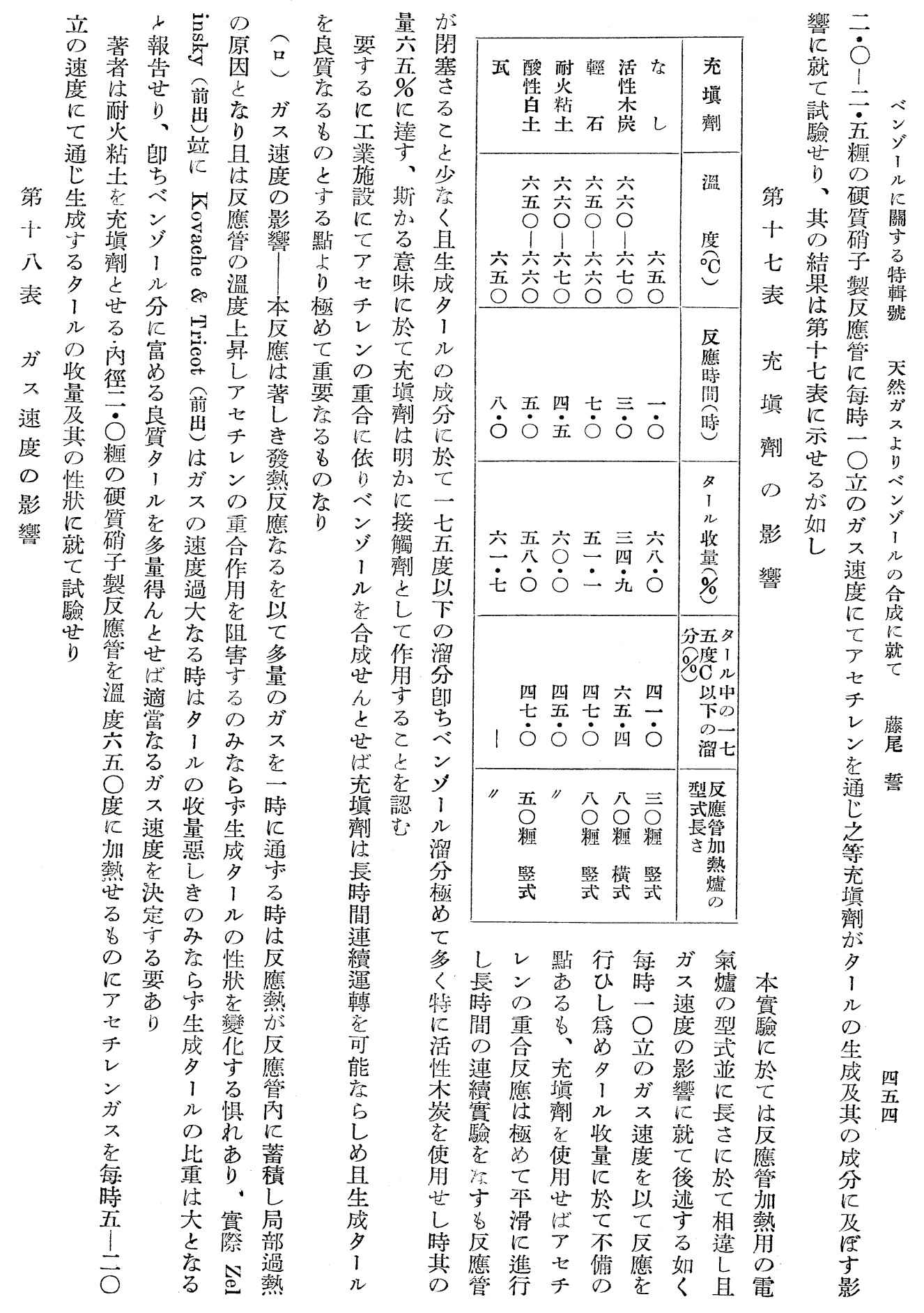


號九十三百 第

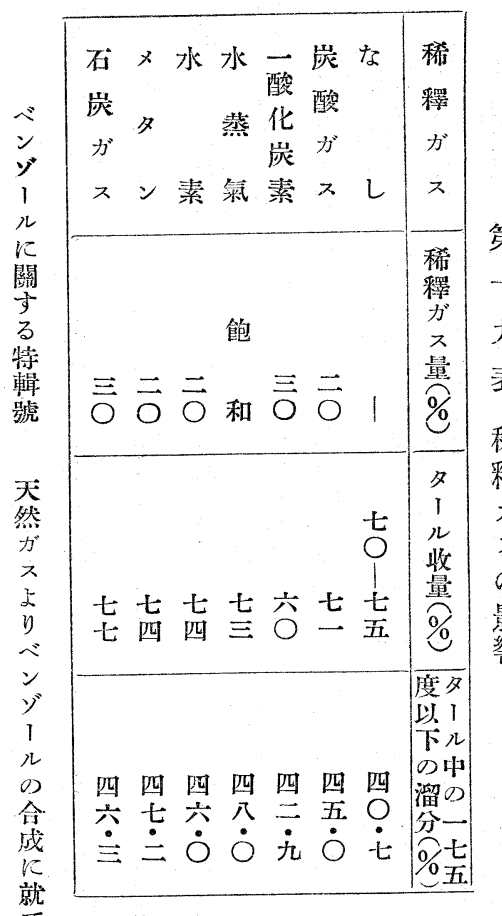

四蒸 ガ然ン除

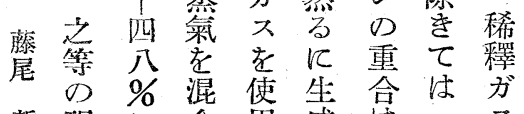

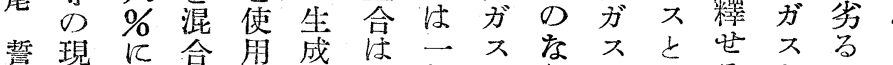

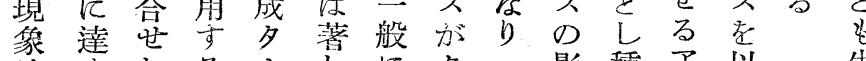

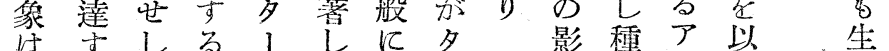

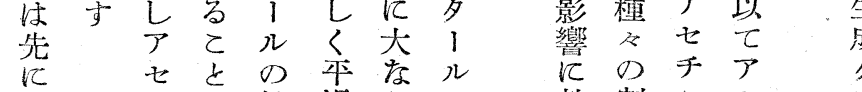

想 チ性滑 ら市就割レセ

像レ依寎にざ收て合ンチ

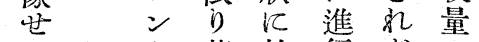

しを著於行に゙に

如 使 $匚 \tau$ ᄂ 占 及

本 角增七特稀 瓜

反斻五長ガ影

四應其 L 度時

五㤎の特以間の度

五、發

效量水卡連在酸

䓜溜續飞华

應次分運依炭

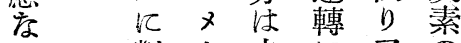

る 對多之江学少

た证等適セ場

發四及稀主手合

五 $儿$ 夕 票 $ン$ 五 1
ぶ用ガ果。门は

如 ᄂ

、七ー へ ガて

本チ酸き稀 ス平

貫レ华や釋速滑

にの素喜火尘淮

重の時行

は袁蒸弎影五年

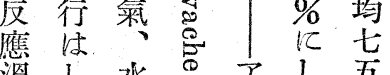

洞 水学无

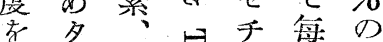

宍 $1 \times$ 总時夕

度收、前ガ章を

ガ量炭速四成

其ガは度五し

の

学素加 点高

每飞七又減乍分

時及千タる夕

五、㷉

と名の老にの先

等稀 以種品り

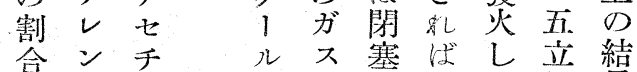

試に速さ方主以果

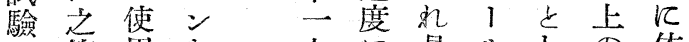

せ等角字七に易ルしの依

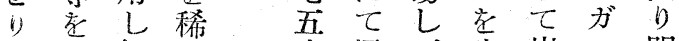

、混好繹度通、生㟤不明

其合結 L 以视成素速

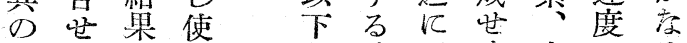

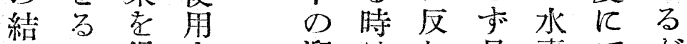

果ア得す溜はし且素てが

は七たる分宁宁沈通如

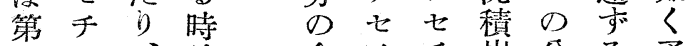

十 $、$ 壮会千千炭分るア

九ン著如量レレ素解時セ

表ガ暮何店ンン少行アチ

にスはを每のを第はセレ

示を炭る 時重每めれチン

守使酸結合時反重レ存 
磁 ニ ア

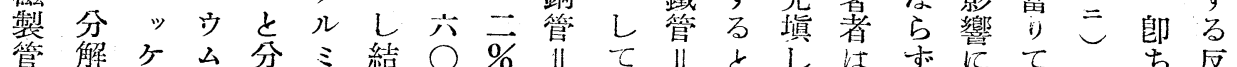

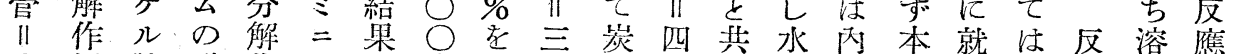

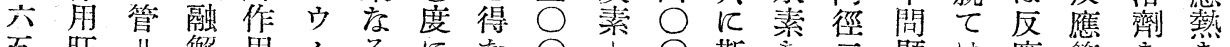

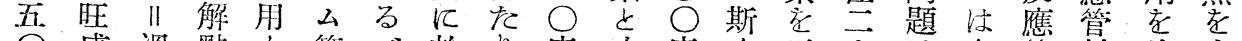

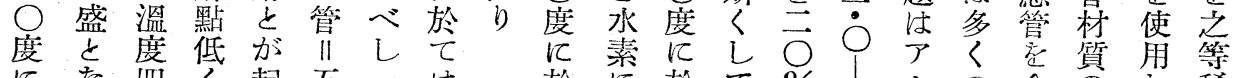

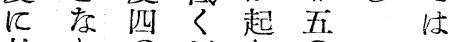
於 D $\bigcirc$ 反 最多應褐 ○

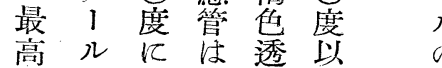
七刀於切明卡收

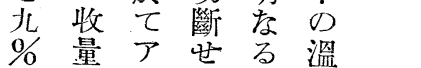
量 ア

夕減子 1 亿

少 $2 儿$ 於

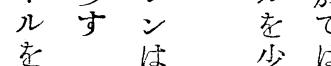

得秒量学

平分解成チ占

七 L ᄂ 2 使

七部六公墕

吾重合度少解

○台质間

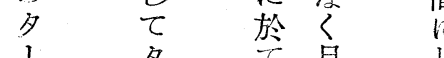

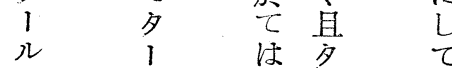

綮銅

量 拿亦管

、成昹生切

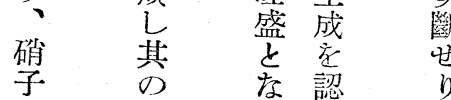

管 量 引

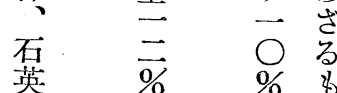

英管 $\quad \begin{array}{lll}\% & \% & \%\end{array}$

使俈多六

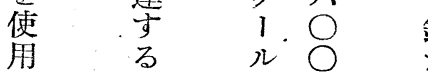

せ \& を度方

L 五得泟的

場 0 た於

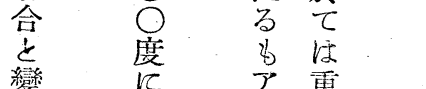

䇠

を 它吉作合 於に於て \%上七の金の稀關 て 分て 得稀 $・$ 千研屬影 加釋 寸 ア解纹を釋五レ究艾響壓ガる 七しアるガ糎ンあ庄抽ス特 チ短七夕スののる其出が輯 收 $レ$ 時チ lを鐵重当他以法吸號

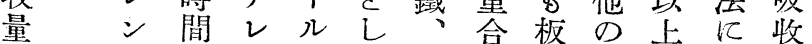

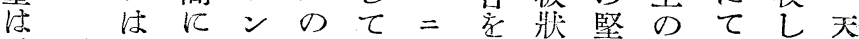
減分ては性混”工を牢實了去然 解反少狀合ヶ業なな驗七り方

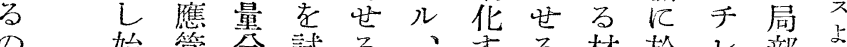

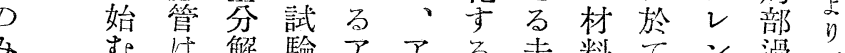

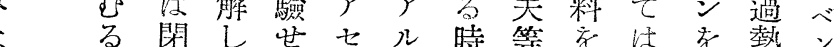
塞五りチミ極金以ア濃笈 ゙゙ 時る $\bigcirc$ 其ンウて唯製チ苂度ル

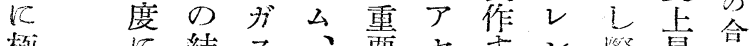

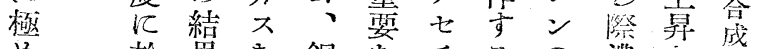

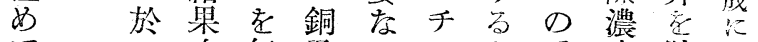
てて次每及ると垂度防就 少はの時鐵間ン必合七步て 量 三如五管 題 0 要定 $\bigcirc$ 尔

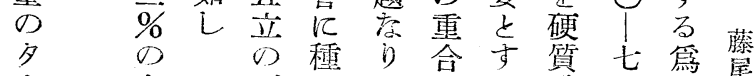

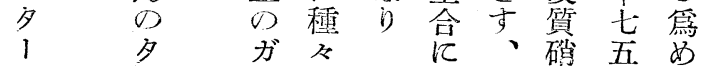
儿 1 而 老速加何方管に七 生を度王疗に昌て子 成生飞衣微は滿と 亡 荿京施影粉石足ン 六。通笈響狀英世及

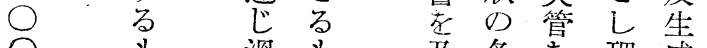
度 六 溫名 ○老及打金角茲 1 $\bigcirc$ 種磁屬L行儿 度亦江方行存の

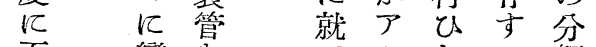
至變索想七し し 解

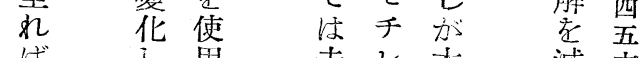
代し用生本減兵

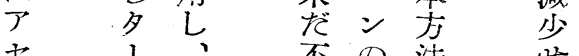

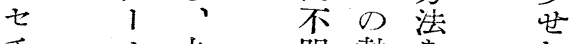
チ光明熱老し

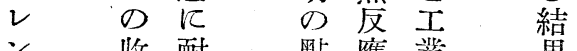
收耐點應承果 は量火多に化应 $\begin{array}{llllll}\text { 主 } & \text { 粘 } & \text { 及 } & \text { る } \\ \text { ¿ } & \text { 測 } & \text { 床 } & \text { る }\end{array}$ 
號九十三百第

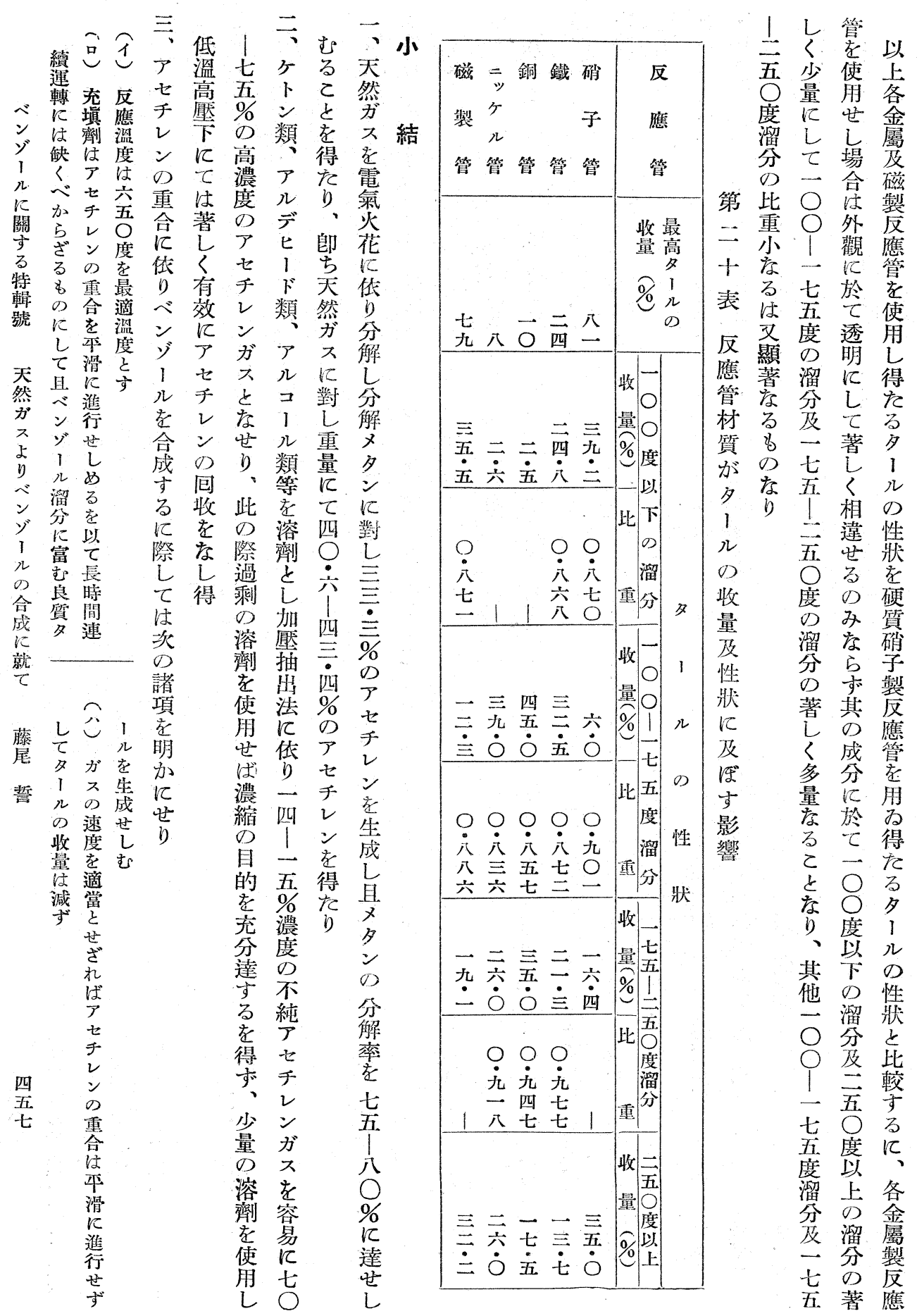


及對合チ續 管操 中田以

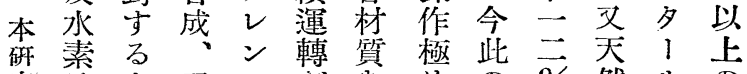
究在夕アにがをめの\%然儿の を各、七變不得て兩注吕を實 行種 ルチ化可難簡方べス生驗

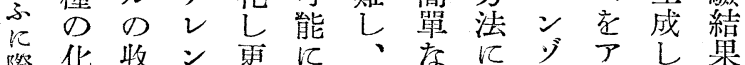

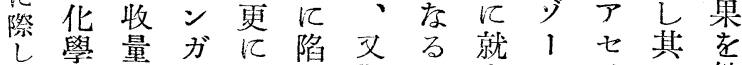

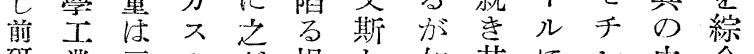
研策亥のが惧か如其にレ中合

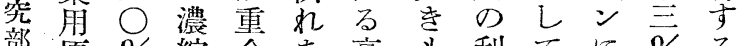
部原 \% 縮 合あ高多利て质\% る

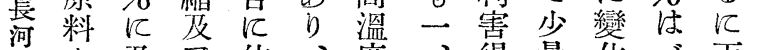
濑之及依、度、得量化今天天 海しびセり特に一失のしン然

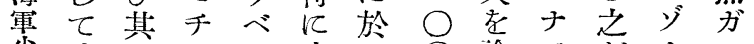

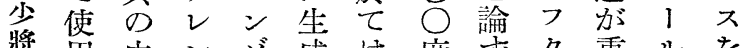
奬角中ンジ成は度等夕重儿を 㨼さ二のI多以るリ合に高 子る り \% 合定儿品早を依七度 絕特のに合のメ高計除り他に 大徵べ依成收夕溫のけべ加 な老ンる年量ン度誹ばンナ熱

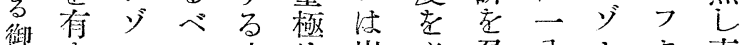

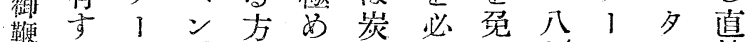

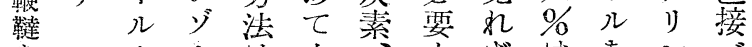

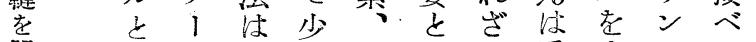

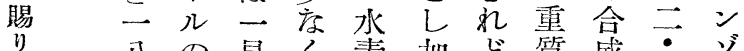

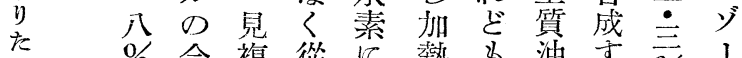

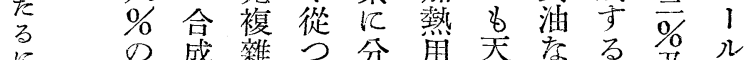

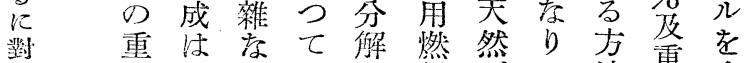

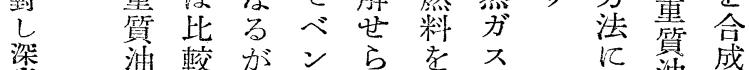

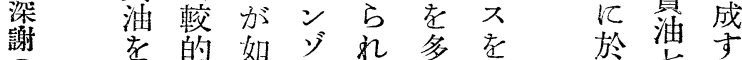
の 合容を1生額高染七方

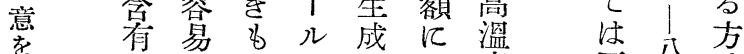
表古江各Dせ要度原分法 等
叉的梯量炭る 加

中得のは素の熱

間て反僅のみL

生其應少雼な直 成の郎なめら接 物生占り、后斯

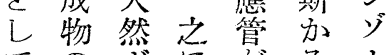

て の 劣 出る

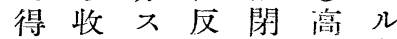
ら 量よ L 塞 溫 考 る 多 b 天空度合 アく原七然言耐威 七料チ不時へる チ忍レを間る方 レスンアの反法 、にの七連應は

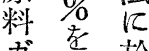

吕得於

比方

對原

L 料

天

$\%$ 然

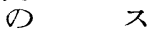

夕

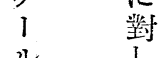

r L

考成

L

其

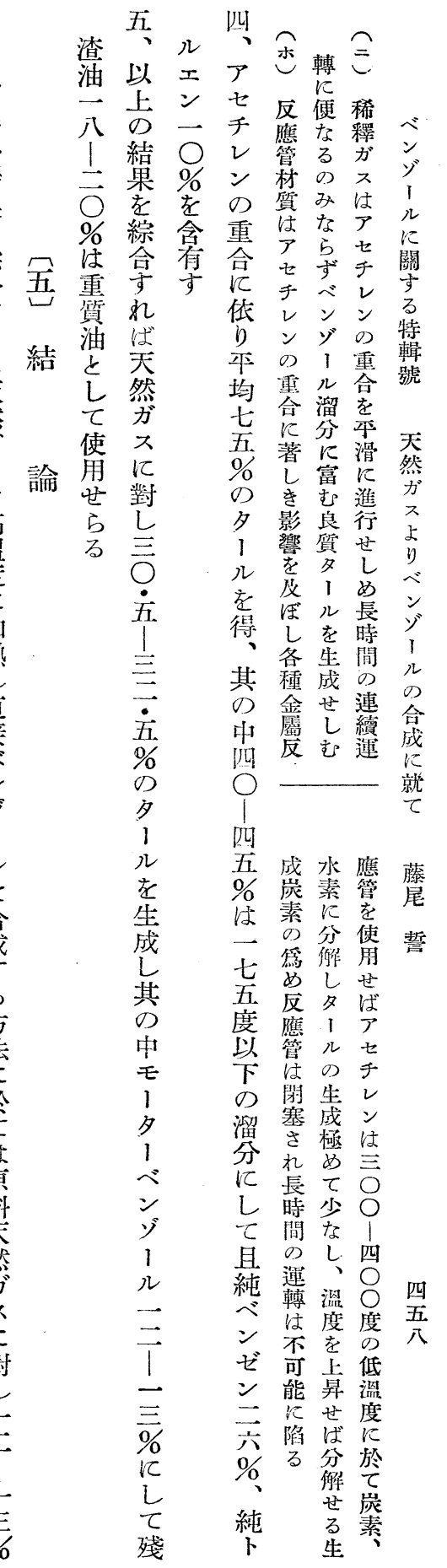

